\title{
LESSONS FROM SOILS DEPOSITED BY THE TSUNAMI AT SENDAI PLAIN IN THE 2011 OFF THE PACIFIC COAST OF TOHOKU EARTHQUAKE
}

\author{
Ken-ichi TOKIDA ${ }^{1}$, Rakhmadyah BAYU2 2 , Ryusuke TANIMOTO3 \\ and Yoshihisa NAKAYAMA 4 \\ ${ }^{1}$ Member of JSCE, Professor, Dept. of Civil Engineering, Osaka University \\ (2-1, Yamada-Oka, Suita, Osaka 565-0871, Japan) \\ E-mail: tokida@civil.eng.osaka-u.ac.jp \\ ${ }^{2}$ Dept. of Business Engineering, Osaka University \\ (2-1, Yamada-Oka, Suita, Osaka 565-0871, Japan) \\ E-mail: rbayu@civil.eng.osaka-u.ac.jp \\ ${ }^{3}$ Student Member of JSCE, Dept. of Civil Engineering, Osaka University \\ (2-1, Yamada-Oka, Suita, Osaka 565-0871, Japan) \\ E-mail: rtanimoto@civil.eng.osaka-u.ac.jp \\ ${ }^{4}$ Member of JSCE, Director, Kansai Geo and Environment Research Center \\ (1-3-3, Higashi-beppu, Settsu, Osaka 566-0042, Japan) \\ E-mail: nakayama@ks-dositu.or.jp
}

\begin{abstract}
On March 11, the 2011 off the Pacific Coast of Tohoku Earthquake occurred and the huge tsunami widely ravaged the coast, carrying sediments inland. Because the sandy layer deposited by the past tsunami is well known to be one of the effective indexes to know the occurrence of the great earthquake in the past, it is very important to investigate the sand sediments left by the above great earthquake.

In this study, a field survey on the soil sediments was conducted at 33 sites of three cross-sections along the Sendai Plain in Miyagi Prefecture. Furthermore, 54 soil samples were dug at each site and grain-size distribution tests were conducted to study the characteristics of the soil sediments in detail.

The results of the study show that the fundamental characteristics of the sediments in this tsunami can be described as "fining upward" and "landward fining", and the relation between the thickness of sand sediments and the distance from the coastline at the Sendai Plain can be obtained from the other investigations.
\end{abstract}

Key Words: earthquake, tsunami, sediment, field survey, grain-size distribution

\section{INTRODUCTION}

In the 2011 off the Pacific Coast of Tohoku Earthquake (hereinafter the 3.11 Earthquake) with a magnitude of 9.0, the sediments were carried inland by the tsunami. The existence of the sand layer created by the tsunami is a very important index to know the time and the magnitude of the past earthquake $^{1)}$. For example, Szczucinski ${ }^{2)}$ reported the relationship on the thickness of sediments in the 2004 Indian Ocean Tsunami, and Sendai City ${ }^{33}$ reported the sand and mud sediments in the 3.11 Earthquake. However, in these reports, the grainsize characteristics of the sediments were not dis- cussed.

In this study, to investigate the state of the soil sediments by the tsunami in the 3.11 Earthquake, three cross-sections at the Sendai Plain were chosen for the field survey. At the field, the composition of deposited layers was investigated and the thickness was measured to know the scale of soil deposits at each site. Moreover, the soils of both deposited layers and original ground located under the sediments were sampled for the laboratory test to know the grain-size distribution in detail.

Based on the grain-size distributions of the sampled soils, the fundamental characteristics of the sediments, such as "fining upward" and "landward 
fining,” can be clarified. Furthermore, comparing with other surveys on the deposited soils, the relationship between the distance from the coastline and the thickness of the sand sediments in this earthquake can be obtained. These field survey results can be applied as the fundamental data to estimate the volume and distribution of sediments for the reconstruction works and the tsunami simulation of the flood depth and flow velocity inland in the future.

\section{STATE OF FIELD DEPOSITS}

\section{(1) Site for field survey}

The survey area was the Sendai Plain where majority of the area was flooded by the tsunami and the water stagnated for several days. As shown in Fig.1, three cross-sections: ARAHAMA at Sendai City; Sendai Airport at Natori City (shown as NORTH AIRPORT); and YOSHIDAHAMA at Yamamoto town located within $2.8-3.3 \mathrm{~km}$ distance from the coastline were chosen. The sites for the field survey and the laboratory test results are shown in Fig.2-4 and Table 1-3, respectively, where the longitude and latitude are also shown. The total sites consist of 9 sites at ARAHAMA, 13 sites at NORTH AIRPORT and 10 sites at YOSHIDAHAMA except 1 site at IDOURA.

In general, the field survey was conducted at relatively stable sites, such as bogs, etc., where environmental conditions were difficult to be changed.

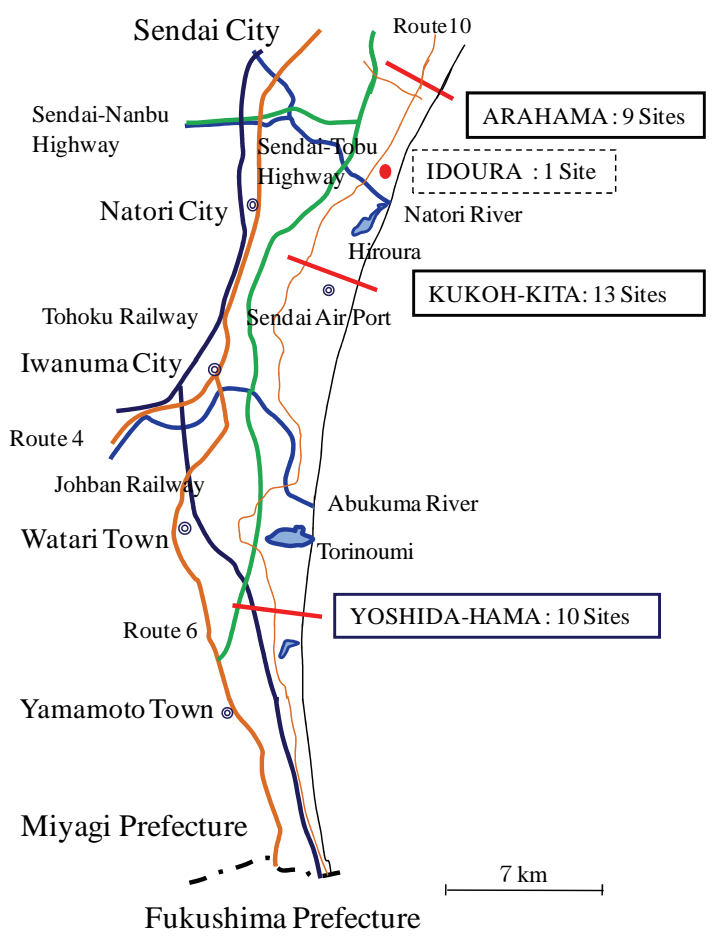

Fig.1 Survey area: Three cross-sections and one independent spot.
However, this field survey was conducted at the paddy fields and arable land due to the recovering activity on the land because it was easy to distinguish the original ground and the sediment layer.

Furthermore, the sediment layer was distinguished by observing the layer color, visual grain size, texture, remaining vegetation and impurity.

The laboratory test results on the soil samples are shown in Table 1-3. There are eight sampling points and 16 samples at ARAHAMA, 12 sampling points and 22 samples at NORTH AIRPORT and 6 sampling points and 16 samples at YOSHIDAHAMA. The total number of samples is 54 . Samplings were not conducted at ARAHAMA No.9, NORTH AIRPORT No.9, YOSHIDAHAMA No.7-10 and IDOURA No.1 where there were no sand deposits.

When the sediments formed several layers, soils were sampled at each layer (for example, sand layer and clay one at ARAHAMA No.4, two sand layers at ARAHAMA Nos.3, 4 and 5, three sand layers at YOSHIDAHAMA No.3 and an original ground with more than one layer at YOSHIDAHAMA No.3).

As shown in Table 1-3, the sediments were classified based on the Japan Soil Classification. Most of the sediments were classified as poorly graded sand "SP" and slightly clayey sand "S-Cs", and most of the original ground consisted of clayey sand "SCs". The original grounds of NORTH AIRPORT No.4, No.6 and No.8 consisted of SP, while No.5, No.7, No.11 were S-Cs. The grain size at NORTH AIRPORT was larger than those at ARAHAMA and YOSHIDAHAMA.

Sites No.3 and No.6 in YOSHIDAHAMA had SCs layer under the SCs layer, while the top layer of sites No.4 and No.7 consisted of sandy clay "CsS". Furthermore, ARAHAMA No.5 consisted of slightly gravely clayey sand "SCs-G".

The field survey was conducted at the end of April in 2012, more than one year after the tsunami. However, it was feared that the site condition had been changed by the transformation of the ground surface, and it was quite sure that there was no significant change because the sites were flat and were not disturbed by human activity and no evidence of dispersed sediment was seen.

\section{(2) State of sediments}

The state of the sediments brought by this tsuna$\mathrm{mi}$ at the representative sites are shown in Table 1-3.

\section{a) ARAHAMA No.3}

This site was once a paddy field and its topography was flat (see Photo 1). This site is close to Route 10 and $10 \mathrm{~m}$ south of a small shrine, which remained undestroyed because it was protected from the tsunami by the trees around it.

Photo 2 shows the pit dug to observe and sample. 


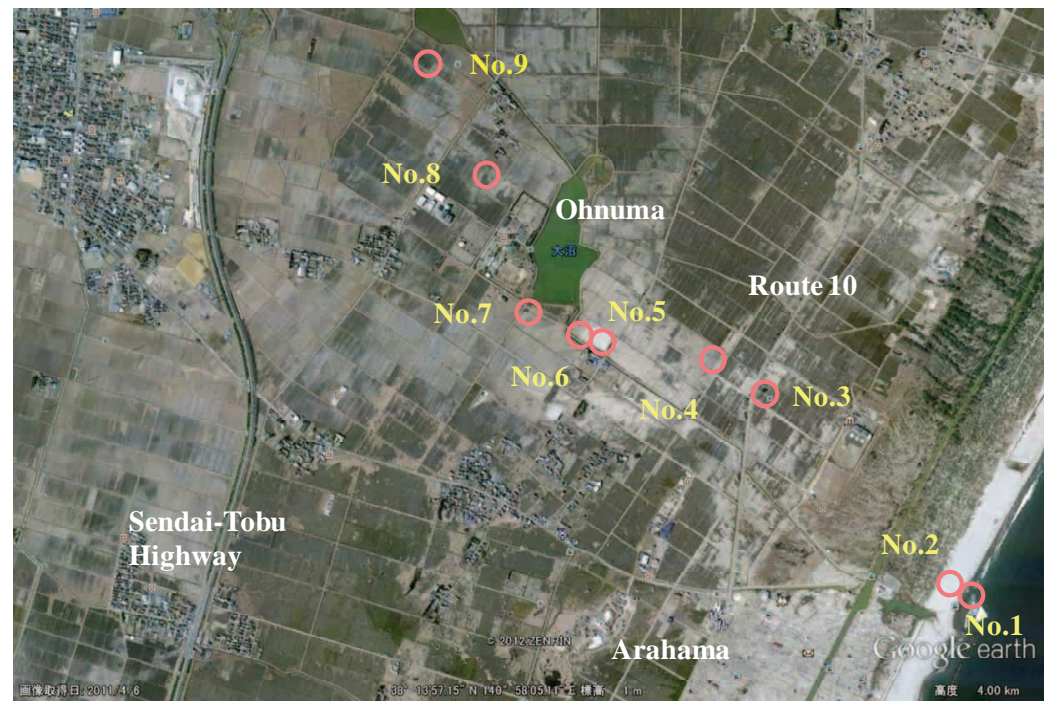

Fig.2 Location of survey sites at ARAHAMA: About $3.3 \mathrm{~km}$ from the coastline.

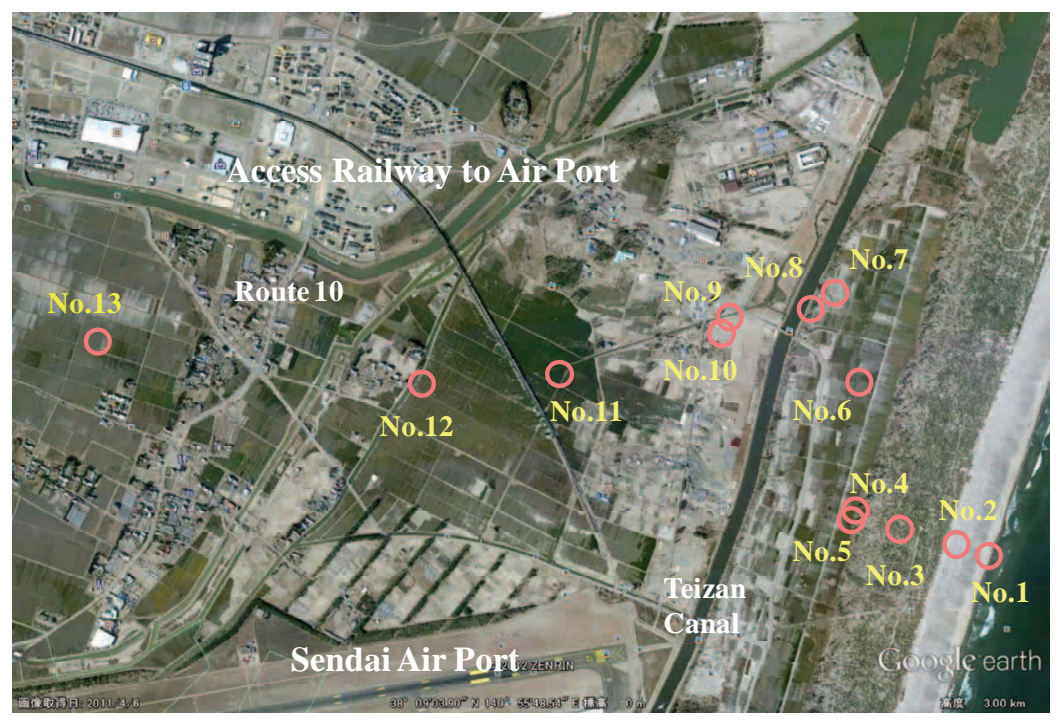

Fig.3 Location of survey sites at NORTH AIRPORT: About $3.3 \mathrm{~km}$ from the coastline.

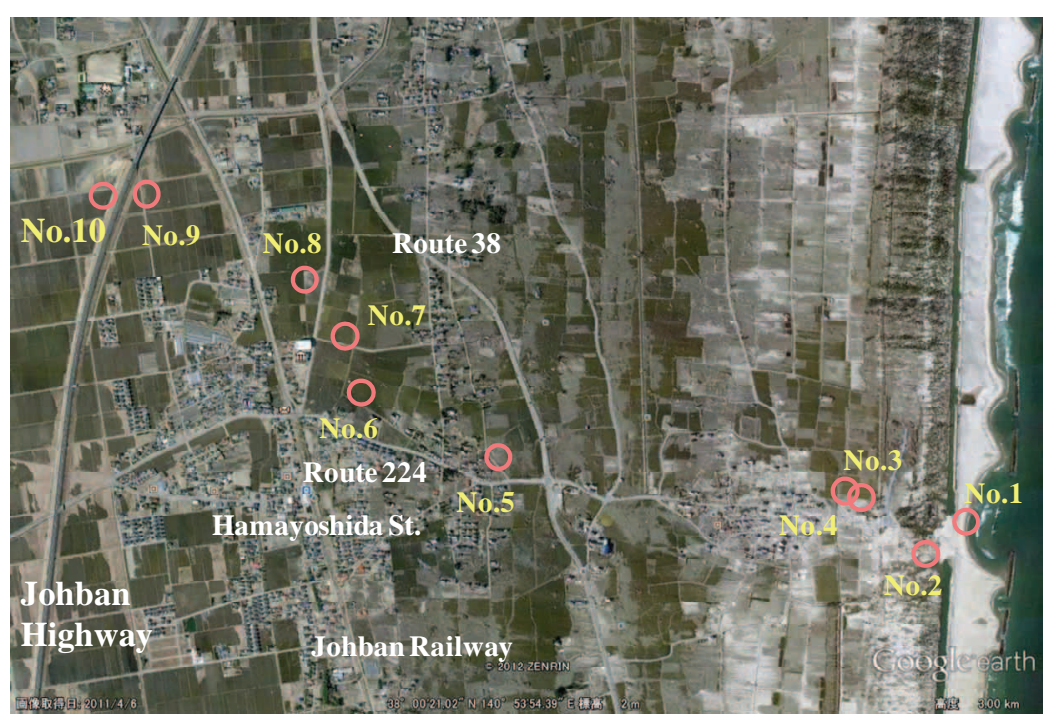

Fig.4 Location of sites at YOSHIDAHANA: About $2.8 \mathrm{~km}$ from the coastline. 
Table 1 Laboratory test results: ARAHAMA.

\begin{tabular}{|c|c|c|c|c|c|c|c|c|c|c|c|}
\hline \multirow{2}{*}{$\begin{array}{l}\text { Site } \\
\text { No. }\end{array}$} & \multirow{2}{*}{$\begin{array}{l}\text { Sample } \\
\text { No. }\end{array}$} & \multirow{2}{*}{$\begin{array}{l}\text { Sediment/ } \\
\text { Ground }\end{array}$} & \multicolumn{2}{|c|}{$\begin{array}{l}\text { Thickness of Sediment } \\
\text { Layer }(\mathrm{cm})\end{array}$} & \multicolumn{3}{|c|}{ Grain Size Distribution (\%) } & \multirow{2}{*}{$\begin{array}{c}\mathrm{D}_{50} \\
(\mathrm{~mm})\end{array}$} & \multirow{2}{*}{$\begin{array}{c}\text { Soil } \\
\text { Classification }\end{array}$} & \multirow{2}{*}{\begin{tabular}{|c|}
$\begin{array}{c}\text { Distance } \\
\text { from } \\
\text { Coastline } \\
(\mathrm{m})\end{array}$ \\
\end{tabular}} & \multirow{2}{*}{$\begin{array}{l}\text { Longitude } \\
\text { Latitude }\end{array}$} \\
\hline & & & Total & Sand & Gravel & Sand & Silt/Clay & & & & \\
\hline 1 & 1 & - & - & - & 0 & 99.6 & 0.4 & 0.32 & SP & 10 & \begin{tabular}{|lllll} 
& 38 & 13 & 18.1 \\
$E$ & 140 & 59 & 22.6
\end{tabular} \\
\hline 2 & 2 & - & - & - & 0 & 100.0 & 0.0 & 0.39 & SP & 90 & \begin{tabular}{|l|} 
N 381319.5 \\
E 1405918.7 \\
\end{tabular} \\
\hline \multirow{3}{*}{3} & $3 \mathrm{U}$ & \multirow{2}{*}{ Sediment } & 8 & \multirow{3}{*}{15} & 0.2 & 93.4 & 6.4 & 0.31 & S-Cs & \multirow{3}{*}{1,230} & N 381350.8 \\
\hline & $3 \mathrm{M}$ & & 7 & & 0.1 & 96.2 & 3.7 & 0.34 & SP & & E 1405848.0 \\
\hline & $3 \mathrm{~L}$ & Ground & - & & 0.1 & 71.5 & 28.4 & 0.26 & SCs & & \\
\hline \multirow{3}{*}{4} & $4 \mathrm{U}$ & \multirow{2}{*}{ Sediment } & 3.5 & \multirow{3}{*}{5} & 0 & 37.1 & 62.9 & 0.017 & CsS & \multirow{3}{*}{1,470} & N 381353.5 \\
\hline & $4 \mathrm{M}$ & & 5 & & 0.5 & 87.3 & 12.2 & 0.28 & S-Cs & & E 1405839.9 \\
\hline & $4 \mathrm{~L}$ & Ground & - & & 0.6 & 69.6 & 29.8 & 0.24 & SCs & & \\
\hline \multirow{2}{*}{5} & $5 \mathrm{U}$ & Sediment & 22 & \multirow{2}{*}{22} & 0.6 & 91.5 & 7.9 & 0.41 & S-Cs & \multirow{2}{*}{1,970} & N 381358.1 \\
\hline & $5 \mathrm{~L}$ & Ground & - & & 7.2 & 72.9 & 19.9 & 0.30 & SCs-G & & E 1405818.9 \\
\hline \multirow{2}{*}{6} & $6 \mathrm{U}$ & Sediment & 3.5 & \multirow{2}{*}{3.5} & 0.3 & 86.5 & 13.2 & 0.28 & S-Cs & \multirow{2}{*}{2,030} & N 381358.9 \\
\hline & $6 \mathrm{~L}$ & Ground & - & & 1.4 & 74.6 & 24.0 & 0.27 & SCs & & E 1405815.4 \\
\hline \multirow{2}{*}{7} & $7 \mathrm{U}$ & Sediment & 1 & \multirow{2}{*}{0} & 0.4 & 25.7 & 73.9 & 0.016 & CsS & \multirow{2}{*}{2,330} & N 381404.0 \\
\hline & $7 \mathrm{~L}$ & Ground & - & & 1.1 & 69.3 & 29.6 & 0.26 & SCs & & E 1405804.4 \\
\hline \multirow{2}{*}{8} & $8 \mathrm{U}$ & Sediment & 2.5 & \multirow{2}{*}{2.5} & 0 & 98.0 & 2.0 & 0.39 & SP & \multirow{2}{*}{2,820} & N 381423.3 \\
\hline & $8 \mathrm{~L}$ & Ground & - & & 1.5 & 78.1 & 20.4 & 0.30 & SCs & & E 1405800.1 \\
\hline 9 & 9 & Ground & 0 & 0 & - & - & - & - & - & 3,310 & $\begin{array}{llll}N & 38 & 14 & 40.5 \\
E & 140 & 57 & 46.2\end{array}$ \\
\hline
\end{tabular}

Table 2 Laboratory test results: NORTH AIRPORT.

\begin{tabular}{|c|c|c|c|c|c|c|c|c|c|c|c|}
\hline \multirow{2}{*}{$\begin{array}{l}\text { Site } \\
\text { No. }\end{array}$} & \multirow{2}{*}{$\begin{array}{c}\text { Sample } \\
\text { No. }\end{array}$} & \multirow{2}{*}{ Sediment/Ground } & \multicolumn{2}{|c|}{ Max. of Thickness (cm) } & \multicolumn{3}{|c|}{ Grain Size Distribution (\%) } & \multirow{2}{*}{$\begin{array}{c}\mathrm{D}_{50} \\
(\mathrm{~mm})\end{array}$} & \multirow{2}{*}{$\begin{array}{c}\text { Soil } \\
\text { Classification }\end{array}$} & \multirow{2}{*}{\begin{tabular}{|l|} 
Distance from \\
Coastline (m)
\end{tabular}} & \multirow{2}{*}{$\begin{array}{l}\text { Latitude N } \\
\text { Longitude E }\end{array}$} \\
\hline & & & Total & Sand & Gravel & Sand & Fine & & & & \\
\hline 1 & 1 & Ground & - & - & 0.0 & 99.7 & 0.3 & 0.34 & SP & 0 & 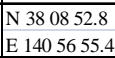 \\
\hline 2 & 2 & Ground & - & - & 0.3 & 99.6 & 0.3 & 0.43 & SP & 90 & $\begin{array}{l}\text { N } 3808 \text { 54.1 } \\
\text { E } 1405651.4\end{array}$ \\
\hline 3 & $3 \mathrm{U}$ & Sediment Sand & 14 & 14 & 1.0 & 98.8 & 0.2 & 0.52 & SP & 290 & N 380854.8 \\
\hline 3 & $3 \mathrm{~L}$ & Ground & - & 14 & 0.6 & 99.1 & 0.3 & 0.34 & SP & 290 & E 1405648.3 \\
\hline 4 & $4 \mathrm{U}$ & Sediment Sand & 13 & 13 & 0.0 & 99.6 & 0.4 & 0.37 & SP & 490 & N 380858.0 \\
\hline 4 & $4 \mathrm{~L}$ & Ground & - & 10 & 0.5 & 95.6 & 3.9 & 0.30 & SP & 490 & E 1405634.8 \\
\hline 5 & $5 \mathrm{U}$ & Sediment Sand & 12 & 12 & 0.0 & 99.6 & 0.4 & 0.34 & SP & 490 & N 380900.5 \\
\hline$J$ & $5 \mathrm{~L}$ & Ground & - & 12 & 0.8 & 87.6 & 11.6 & 0.29 & S-Cs & 450 & E 1405641.7 \\
\hline 6 & $6 \mathrm{U}$ & Sediment Sand & 17 & 17 & 0.3 & 98.9 & 0.8 & 0.35 & SP & 570 & N 380929.0 \\
\hline 0 & $6 \mathrm{~L}$ & Ground & - & 17 & 4.9 & 90.8 & 4.3 & 0.35 & SP & 5/0 & E 1405638.1 \\
\hline 7 & $7 \mathrm{U}$ & Sediment Sand & 28 & 78 & 0.4 & 95.0 & 4.6 & 0.34 & SP & 750 & N 380859.2 \\
\hline 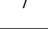 & $7 \mathrm{~L}$ & Ground & $\begin{array}{ll}-- \\
-\end{array}$ & 20 & 3.0 & 86.4 & 10.6 & 0.36 & S-Cs & 150 & E 1405514.7 \\
\hline 8 & $8 \mathrm{U}$ & Sediment Sand & 19 & 19 & 0.0 & 99.1 & 0.9 & 0.33 & SP & 820 & N 380903.7 \\
\hline 0 & $8 \mathrm{~L}$ & Ground & - & 19 & 0.1 & 95.9 & 4.0 & 0.32 & SP & 020 & E 1405527.3 \\
\hline 9 & 9 & Sediment at Chanal & 23 & - & - & - & - & - & - & - & N 380908.5 \\
\hline$J$ & J & Je & 20 & 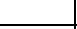 & - & 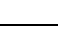 & - & - &  & 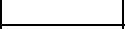 & E 1405616.5 \\
\hline 10 & $10 \mathrm{U}$ & Sediment Sand & 14 & 14 & 3.5 & 93.2 & 3.3 & 0.41 & SP & 1.100 & N 380850.3 \\
\hline 10 & $10 \mathrm{~L}$ & Ground & - & & 2.1 & 81.0 & 16.9 & 0.29 & SCs & 1,100 & E 1405519.9 \\
\hline 11 & $11 \mathrm{~L}$ & Sediment Sand & 14 & 14 & 1.6 & 97.7 & 0.7 & 0.38 & SP & 1,560 & N 380903.0 \\
\hline & $11 \mathrm{~L}$ & Ground & - & 14 & 0.4 & 85.7 & 13.9 & 0.31 & S-Cs & & E 1405552.2 \\
\hline 12 & $12 \mathrm{U}$ & Sediment Sand & 13 & 13 & 0.0 & 94.3 & 5.7 & 0.27 & S-Cs & 1.950 & N 380901.7 \\
\hline & $12 \mathrm{~L}$ & Ground & - & 13 & 0.0 & 45.2 & 54.8 & 0.028 & CsS & 1,950 & E 1405533.2 \\
\hline 13 & $13 \mathrm{U}$ & Sediment Sand & 2 & 2 & 0.0 & 85.2 & 14.8 & 0.24 & S-Cs & 3060 & N 380907.2 \\
\hline 13 & $13 \mathrm{~L}$ & Ground & - & 2 & 0.5 & 44.7 & 54.8 & 0.034 & CsS & 3,000 & E 1405447.4 \\
\hline
\end{tabular}

Table 3 Laboratory test results: YOSHIDAHAMA.

\begin{tabular}{|c|c|c|c|c|c|c|c|c|c|c|c|}
\hline \multirow{2}{*}{$\begin{array}{l}\text { Site } \\
\text { No. }\end{array}$} & \multirow{2}{*}{$\begin{array}{c}\text { Sample } \\
\text { No. }\end{array}$} & \multirow{2}{*}{ Sediment/Ground } & \multicolumn{2}{|c|}{ Max. of Thickness (cm) } & \multicolumn{3}{|c|}{ Grain Size Distribution (\%) } & \multirow{2}{*}{$\begin{array}{c}\mathrm{D}_{50} \\
(\mathrm{~mm})\end{array}$} & \multirow{2}{*}{$\begin{array}{c}\text { Soil } \\
\text { Classification }\end{array}$} & \multirow{2}{*}{$\begin{array}{l}\text { Distance from } \\
\text { Coastline }(\mathrm{m})\end{array}$} & \multirow{2}{*}{$\begin{array}{l}\text { Latitude N } \\
\text { Longitude E }\end{array}$} \\
\hline & & & Total & Sand & Gravel & Sand & Fine & & & & \\
\hline 1 & 1 & Ground & - & - & 0.0 & 99.1 & 0.9 & 0.32 & SP & 0 & \begin{tabular}{|llll} 
N 38 & 00 & 00.4 \\
E 140 & 54 & 55.3 \\
\end{tabular} \\
\hline 2 & 2 & Ground & - & - & 0.0 & 98.9 & 1.1 & 0.32 & SP & 120 & $\begin{array}{llll} & 38 & 00 & 01.5 \\
\text { E } 140 & 54 & 50.7\end{array}$ \\
\hline \multirow{6}{*}{3} & $3 \mathrm{U}$ & Sediment Sand & 5 & \multirow{6}{*}{12} & 0.0 & 97.5 & 2.5 & 0.26 & SP & \multirow{6}{*}{390} & N 380006.2 \\
\hline & $3 \mathrm{M}$ & Sediment Sand & 7 & & 0.0 & 98.9 & 1.1 & 0.28 & SP & & E 1405437.6 \\
\hline & 3L1 & Boiled Sand & 7 & & 0.6 & 92.8 & 6.6 & 0.33 & S-Cs & & \\
\hline & 3L2 & Ground Clay & 10 & & 0.9 & 72.5 & 26.6 & 0.25 & SCs & & \\
\hline & 3L31 & \multirow{2}{*}{ Ground Sand } & - & & 0.0 & 94.2 & 5.8 & 0.27 & S-Cs & & \\
\hline & 3L32 & & - & & 0.8 & 93.9 & 5.3 & 0.25 & S-Cs & & \\
\hline \multirow{3}{*}{4} & $4 \mathrm{U}$ & Sediment Sand & 14 & \multirow{3}{*}{14} & 0.0 & 96.6 & 3.4 & 0.23 & SP & \multirow{3}{*}{440} & N 380006.4 \\
\hline & $4 \mathrm{M}$ & Sediment Sand & 14 & & 0.1 & 99.1 & 0.8 & 0.31 & SP & & E 1405436.9 \\
\hline & $4 \mathrm{~L}$ & Ground & & & 0.1 & 72.8 & 27.1 & 0.24 & SCs & & \\
\hline \multirow{3}{*}{5} & $5 \mathrm{U}$ & Sediment Sand & 13 & \multirow{3}{*}{13} & 0.0 & 96.8 & 3.2 & 0.23 & SP & \multirow{3}{*}{1,590} & N 380014.4 \\
\hline & $5 \mathrm{M}$ & Sediment Sand & 13 & & 0.1 & 93.4 & 6.5 & 0.30 & S-Cs & & E 1405416.7 \\
\hline & $5 \mathrm{~L}$ & Ground & - & & 1.7 & 71.9 & 26.4 & 0.30 & SCs & & \\
\hline \multirow{3}{*}{6} & $6 \mathrm{U}$ & Sediment Sand & 6 & \multirow{3}{*}{6} & 0.0 & 92.9 & 7.1 & 0.25 & S-Cs & \multirow{3}{*}{2,090} & N 380010.2 \\
\hline & $6 \mathrm{M}$ & \multirow{2}{*}{ Ground } & 4 & & 0.7 & 76.8 & 22.5 & 0.26 & SCs & & \multirow[t]{2}{*}{ E 1405351.1} \\
\hline & $6 \mathrm{~L}$ & & - & & 0.6 & 84.7 & 14.7 & 0.30 & S-Cs & & \\
\hline 7 & - & Ground & - & 0 & - & - & - & - & - & 2,120 & \begin{tabular}{|lllll} 
& 38 & 00 & 24.7 \\
& 140 & 53 & 27.1
\end{tabular} \\
\hline 8 & - & Ground & - & 0 & - & - & - & - & - & 2,280 & N 380034.0 \\
\hline 9 & & & & & & & & - & - & 2810 & \begin{tabular}{|l|l|l} 
& 140 \\
& 380034.8 \\
\end{tabular} \\
\hline 9 & - & Ground & thin & 0 & - & - & - & - & - & 2,810 & E 1405300.9 \\
\hline 10 & - & Ground & - & 0 & - & - & - & - & - & 2,960 & \begin{tabular}{|llll}
$N$ & 38 & 00 & 19.8 \\
& 140 & 52 & 53.0
\end{tabular} \\
\hline
\end{tabular}




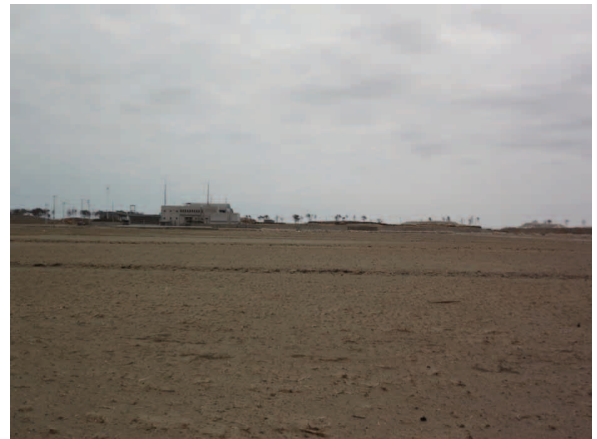

Photo 1 ARAHAMA No. 3: Facing the sea.

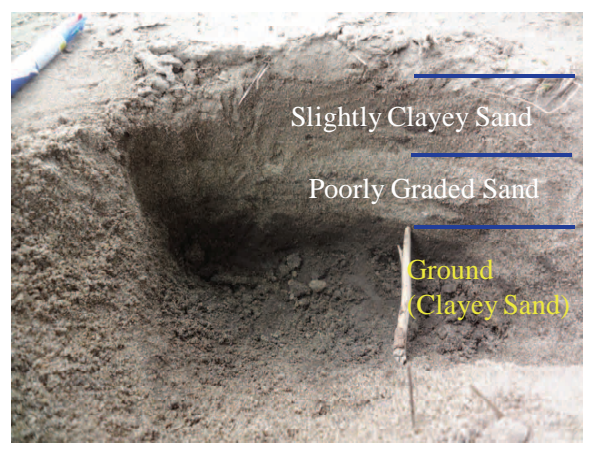

Photo 2 Two sand layers of sediment.

The sediments were deposited above the SCs ground, which consisted of $71.5 \%$ sand and $28.4 \%$ fine particles. The coarse particle diameter of sediments was around $0.075-2 \mathrm{~mm}$, while the fine one was less than $0.075 \mathrm{~mm}$. The thickness of sand deposit was $15 \mathrm{~cm}$. The color of the sand deposit was different, i.e., the upper layer with the thickness of $8 \mathrm{~cm}$ was darker and the lower layer with $7 \mathrm{~cm}$ was lighter or whitish. Therefore, two soil samples were taken at this site to distinguish each layer. The grain-size test result showed that the upper layer was classified as S-Cs, which consisted of $93.4 \%$ sand and $6.4 \%$ fine particles. The lower layer was classified as SP, which consisted of $96.2 \%$ sand and $3.7 \%$ fine particles. Therefore, particles at the upper layer were finer than those at the lower layer. This result suggests that grain-size characteristic was different between the upper and lower layers even though they were located at the same site. The characteristic of the grain-size distribution where the upper layer was finer than the lower layer indicates that the upper layer underwent a slower deposit than that of the lower one.

\section{b) ARAHAMA No.4}

This site is located on the west relative to site No.3, and about $100 \mathrm{~m}$ west from Route No.10. The site is located at flat paddy fields and a little far from the walking paths, and the sediments at this site were considered to be unaffected by the surrounding conditions.

Photo 4a shows the pit at this site. The original ground was classified as SCs, which consisted of

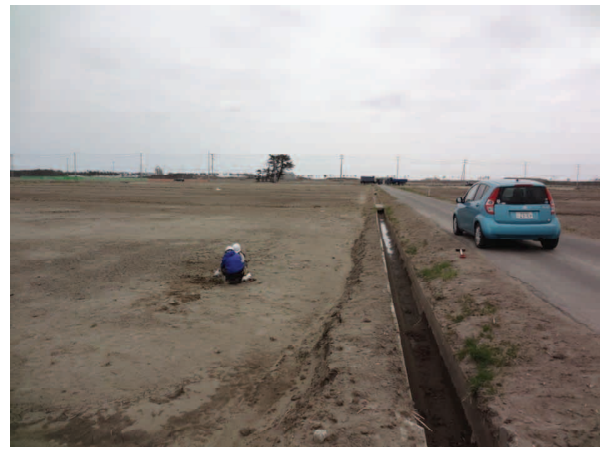

Photo 3 ARAHAMA No. 4: Facing the sea.

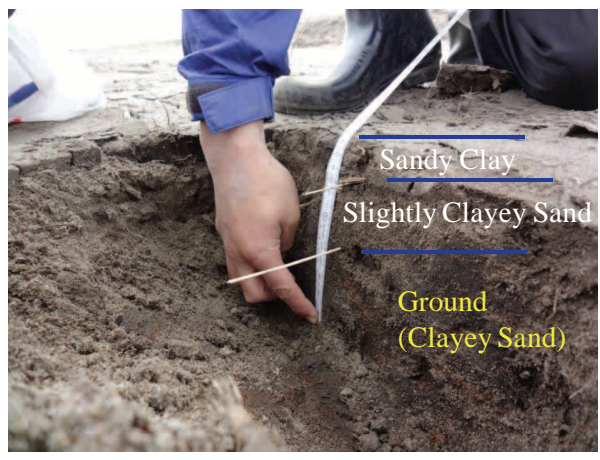

a) ARAHAMA No.4

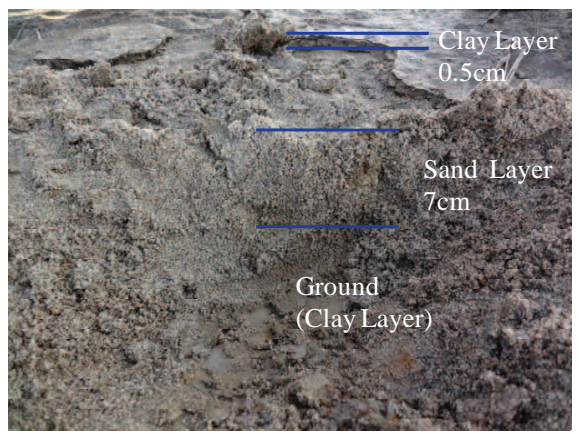

b) IDOURA No.1

Photo 4 Example of 3-layers structure.

69.6\% sand and $29.8 \%$ fine particles. The sediment layer was divided into two layers. The upper layer was classified as CsS, which consisted of $37.1 \%$ sand and $62.9 \%$ clay with thickness of $2-3.5 \mathrm{~cm}$. The lower layer was classified as S-Cs, which consisted of $87.3 \%$ sand and $12.2 \%$ fine particles with thickness of 2-5 cm.

As shown above, the three-layer structure with the original ground and two types of sediments, such as the sand and clay layers, could be found only at ARAHAMA No.4 and IDOURA No.1 as shown in Photo $4 \mathbf{b}$ in this survey. On the other hand, many three-layer structures on the sediments were reported by Sendai City ${ }^{3)}$ as will be shown later.

Comparing the upper layer at this site with the upper layer at ARAHAMA No.3, the former was finer than the latter. Because this site is located farther from the coastline than ARAHAMA No.3, it 


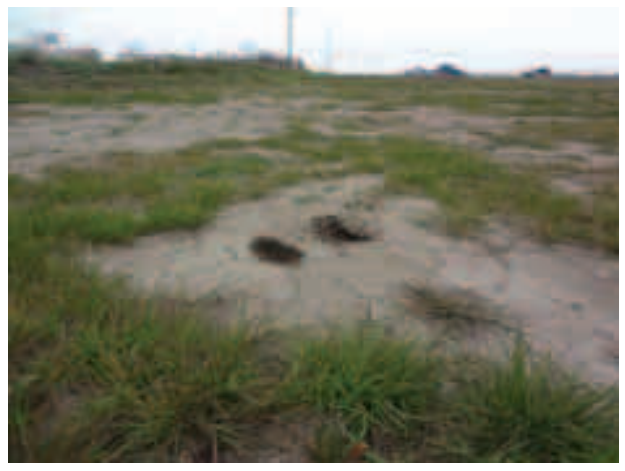

Photo 5 ARAHAMA No. 7: Facing the sea.

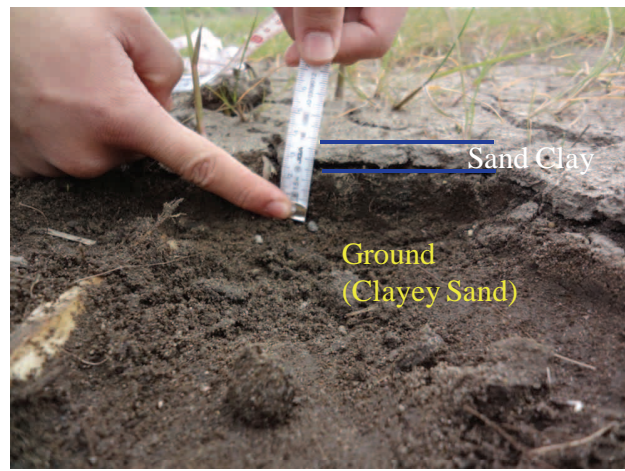

Photo 6 Clayey sediment in ARAHAMA No. 7.

indicates that the former was deposited slowly under the flood condition after the tsunami.

\section{c) ARAHAMA No.7}

This site is located close to the south east corner of the intersection of the farm road, which is at the south east of the Agricultural and Horticultural Center. There is a park at the north side and a waterway at the west side. A field with flat topography can be found in the east direction (see Photo 5).

As shown in Photo 6, there were $1 \mathrm{~cm}$ tortoiseshaped dry sediments above the original ground, which seemed to be clay. The result of the grain-size test showed that it was classified as CsS, which consisted of $25.7 \%$ sand and $73.9 \%$ fine particles. The original ground was classified as SCs, which consisted of $69.3 \%$ sand and $29.6 \%$ fine particles.

The appearance of this thin dry layer at the surface showed an obvious difference from the original ground. Moreover, the fine particles were almost similar to the upper layer of ARAHAMA No.4. Thus it can be deduced that the thin layer was of the clay sediment different from the original ground.

There was only clay deposit at this site and no sand deposit was found. Also, among all sites in this survey, such condition was found only at this site.

\section{d) NORTH AIRPORT No.5}

This site is located $5 \mathrm{~m}$ to the south of NORTH AIRPORT No.4. As shown in Photo 7, there were swamps created by the tsunami and forest reserve at the east side, which indicates the coast. This photo-



Photo 7 NORTH AIRPORT No. 5: Facing site No. 4 on the north.

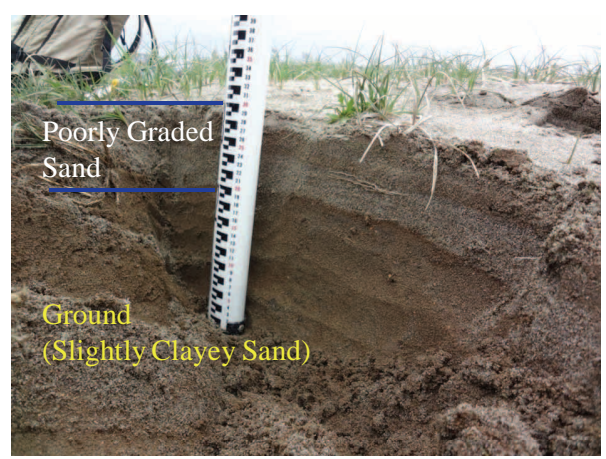

Photo 8 Sand deposit on original sandy ground.

graph also shows the young buds of reeds growing at this site. According to the satellite image taken before this tsunami, this site seemed to be a farm land originally. The original ground at this site was sand (see Photo 8) with thickness of $8.5-12 \mathrm{~cm}$. The maximum thickness of $12 \mathrm{~cm}$ is shown as a representative thickness in Table 2.

The sediments at this site had two different layers: the brownish upper sand layer and whitish lower sand layer. Because this site was the first doublelayer case on the sediments in this survey, only one soil sample was taken although there were two different layers. However, after this site, for every multiple layers on the sediments, soil sampling was attempted at every layer.

The ground was classified as S-Cs, which consisted of $87.6 \%$ sand and $11.6 \%$ fine particles, and the sediment was classified as SP, which consisted of $99.6 \%$ sand and $0.4 \%$ fine particles. The ground was originally sand dune and sand sediments were deposited above it. Since both of them were sand, it is important to distinguish the original ground and the sediments.

\section{e) NORTH AIRPORT No.7}

The topography of this site is flat. Far away at the east side, there was a forest reserve, and far away at the west side, there was a canal called Teizan Canal. As shown in Photo 9, this area was covered by many dead reeds, and young buds had grown among the dead reeds, which might have grown before tsu- 


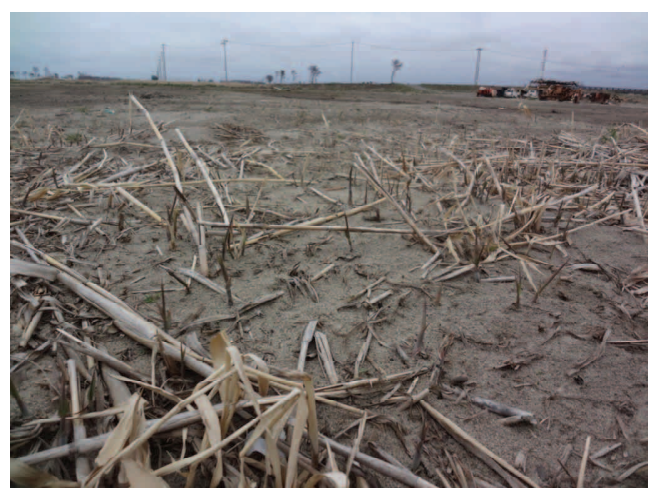

Photo 9 NORTH AIRPORT No. 7: Facing south.



Photo 10 Reeds growing through sand deposit.

nami. As shown in Photo 10, there were new reeds growing in the sediments after the tsunami.

The thickness of the sediments was $24-28 \mathrm{~cm}$. The maximum thickness of $28 \mathrm{~cm}$ is shown as a representative one in Table 2. A PVC pipe $(3.5 \mathrm{~cm}$ in diameter and $70 \mathrm{~cm}$ long) was found buried in the sand sediments, which seemed to be carried by the tsunami.

There were two deposited layers at this site. The upper layer was whitish in color and was classified as SP, which consisted of $95.0 \%$ sand and $4.6 \%$ fine particles. The lower layer was blackish in color and classified as S-Cs, which consisted of $86.4 \%$ sand and $10.6 \%$ fine particles. Based on an observation of the pit, it seemed that the lower layer was the original ground. This site contained fewer fine particles than that of the paddy field at ARAHAMA. In addition, the original ground at sites No.4, No.6, and No.8 were classified as SP.

From this site, two important points can be deduced. First, because the vegetation condition changed after the tsunami, it is important to pay attention to vegetation condition on the field survey. Second, even though most original ground was clay, the original ground could have been sand sometimes. f) NORTH AIRPORT No.13

This site is located $3.6 \mathrm{~km}$ away from the coastline. It is a paddy field. Therefore, the topography is flat as shown in Photo 11. Photo 12 shows the pit at

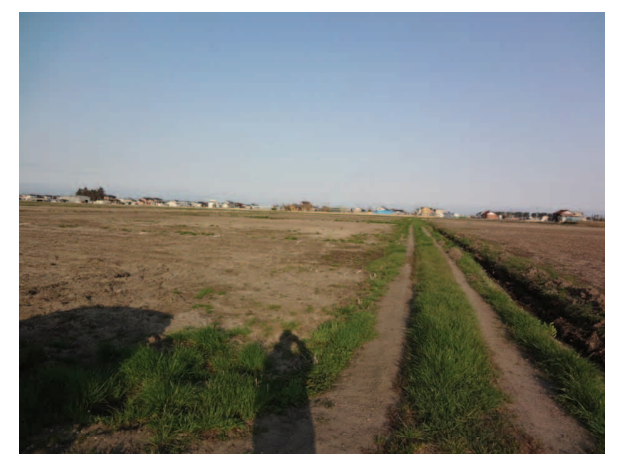

Photo 11 NORTH AIRPORT No. 13: Facing east.

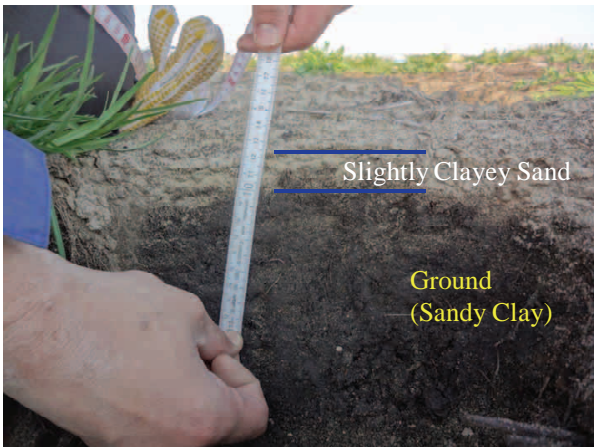

Photo 12 Thin sediment laver far awav from the coastline.

this site. In this site, the thickness of the sediments was $2 \mathrm{~cm}$. Based on the result of the grain-size test, it was classified as S-Cs, which consisted of $85.2 \%$ sand and $14.8 \%$ slightly finer particles. The original ground was classified as CsS, which consisted of $44.7 \%$ sand and $54.8 \%$ fine particles.

Compared with other sites, the amount of fine particles was increasing the farther they were from the coastline. This indicates that the fine particles, due to their light weight, were easily carried far from the coastline.

\section{g) YOSHIDAHAMA No.3}

Even though the detached breakwaters were constructed along the coastline as shown in Fig.4, the sea walls at the back side of the sand beach were destroyed by the tsunami, and the inland was flooded severely.

This site is located $400 \mathrm{~m}$ west from the coastline. According to the local people, this area was once a paddy field. The north part of this site was a farm land and there was a forest reserve behind the sea wall at the east side. The west side was vacant with flat topography, and the south side was once a residential area. Furthermore, the east side of this paddy field was not yet flooded when the field survey was conducted.

Photo 13 shows several sand-boiled craters. The sediments around the crater were examined minutely to know the characteristic of sediments influenced by soil liquefaction. 


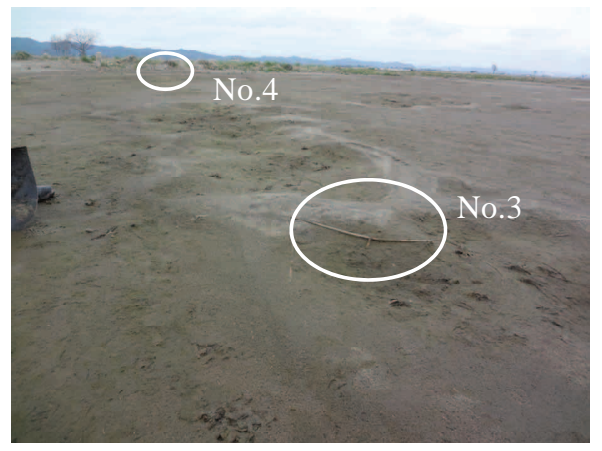

Photo 13 YOSHIDAHAMA No. 13: Facing west.

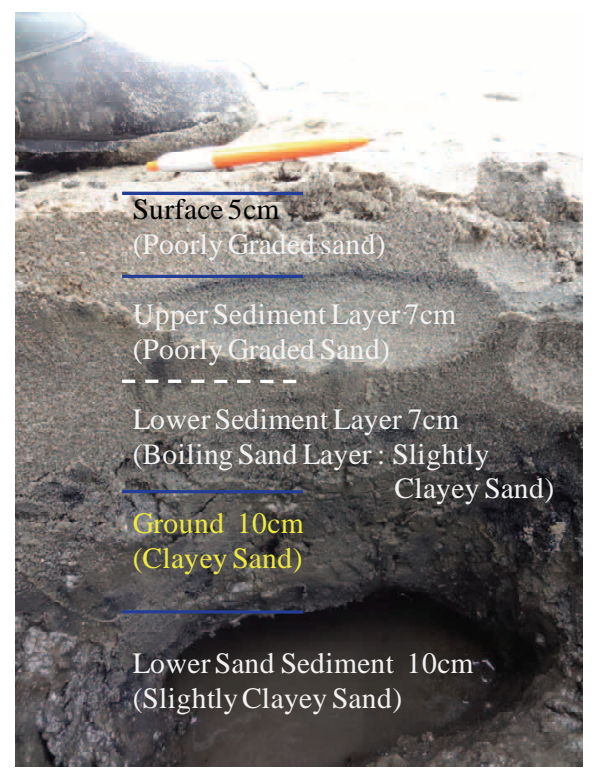

Photo 14 Boiled sand layer and sand sediment layer.

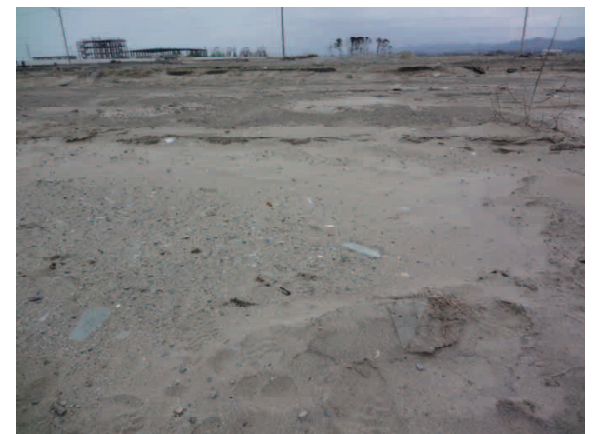

a) Debris found near the remnants of a residential area

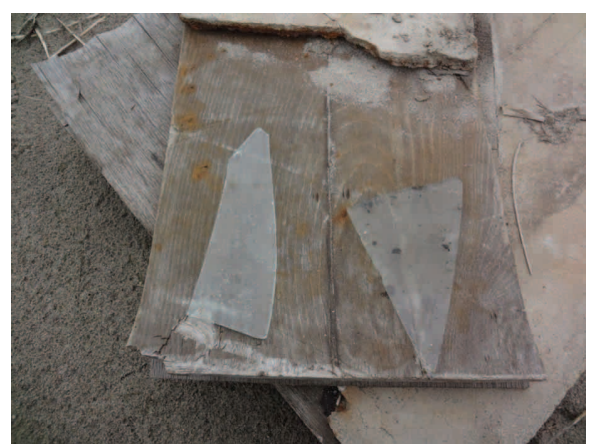

b) Glass shards found in a residential area (left) and sand sediment layer (right)

Photo 15 Glass shards on and in sediments.

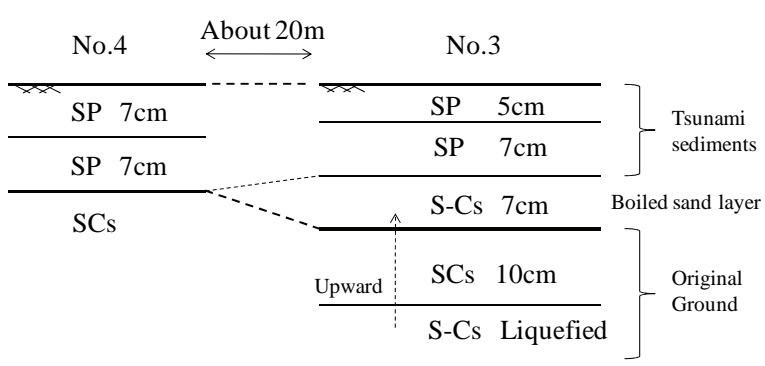

Fig.5 Comparison of No.3 and No.4 sites.

Photo 14 shows the layers of site No.3. On the surface, there was a sand layer that was classified as SP, which consisted of $97.5 \%$ sand and $2.5 \%$ fine particles. The thickness of this layer was $5 \mathrm{~cm}$. Under this layer, there was a sand deposit layer with thickness of $14 \mathrm{~cm}$. Furthermore, under this layer, there was the original ground classified as SCs, which consisted of $72.5 \%$ sand and $26.6 \%$ fine particles.

The deposit layer consisted of two different layers which were $7 \mathrm{~cm}$ thick each. The upper layer was classified as SP, which consisted of $98.9 \%$ sand and $1.1 \%$ fine particles. In this layer, much glass shards and ceramic debris were found as shown in Photo 15. They were also found on the surface at the residential area $10 \mathrm{~m}$ into the south direction. Thus, it can be estimated that those shards and debris were carried by the tsunami to this site from the neighboring residential areas. The lower layer of sand deposit was classified as S-Cs, which consisted of $92.8 \%$ sand and $6.6 \%$ fine particles.

To know the origin of the boiled-sand on the ground surface, deeper scouring was attempted until another layer was found. Another sand layer was found $10 \mathrm{~cm}$ downward from the border of sand deposits and original ground, which was classified as S-Cs and consisted of $94.2 \%$ sand and 5.8\% fine particles. The origin of boiled sands will be further discussed in Chapter 3.

On the same paddy field about $20 \mathrm{~m}$ far west from No.3, there was site No.4 close to the path of the paddy field where sand-boiled craters could not be found. The original ground under the sand sediments was a clay layer classified as SCs, which consisted of $72.8 \%$ sand and $27.1 \%$ fine particles. Therefore, the soils at site No.4 were classified as the same with the original ground at site No.3 as shown in Fig.5.

Moreover, at site No.4, the sand sediments were classified as SP. The thickness of the sediment layer was $14 \mathrm{~cm}$ and it was divided into two layers: the upper and lower sand layers. The upper layer consisted of $96.6 \%$ sand and $3.4 \%$ fine particles, while the lower layer consisted of $99.1 \%$ sand and $0.8 \%$ fine particles. However, there were less fine parti- 
cles than that in the lower layer of No.3. Thus, it can be estimated that the two layers at site No. 4 were the sediments carried by the tsunami.

Comparing site No.3 with site No.4, it can be concluded that not only sediments carried by the tsunami but also sediments boiled by soil liquefaction could be observed.

\section{h) YOSHIDAHAMA No.6}

This site is located at the north side of Route No.224 as shown in Fig.4. Photo 16 shows that the topography of the area around this site was flat. Judging from the satellite image before the tsunami, there were no barriers against the tsunami, such as houses, in the east direction, i.e., to the coastline. Also, both west and south directions of this site were residential areas.

The test pit of this site is shown in Photo 17. From the result of the laboratory test, the upper sediment layer was classified as S-Cs, which consisted of $92.9 \%$ sand and $7.1 \%$ fine particles. The lower original ground layer estimated to be the upper and lower layers at the field and the grain-size tests were applied to each layer. The upper layer was classified as SCs, which consisted of $76.8 \%$ sand and $22.5 \%$ fine particles. The lower layer was a blackish layer classified as S-Cs, which consisted of $84.7 \%$ sand and $14.7 \%$ fine particles. Although there was more sand in the lower ground layer, it suggested that both layers were almost the same.

Compared with the original ground, the sand at this site was less than that at YOSHIDAHAMA No.3 and there was sandy layer below the clayey

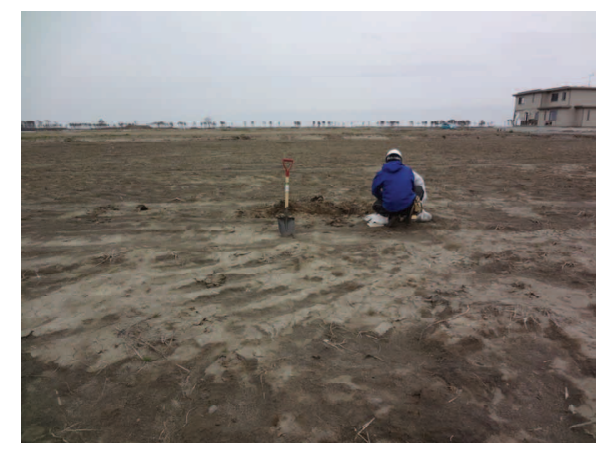

Photo 16 YOSHIDAHAMA No. 6: Facing east.



Photo 17 Sand layer under original clayey ground. ground.

\section{i) YOSHIDAHAMA No.9}

This site is located a few meters far from the east side of the embankment of Joban Highway. As shown in Photo 18, this area is a paddy field. The highway embankment was estimated to serve as a barrier against the tsunami.

Unlike at sites No.7, No.8 and No.10 where there were no sand sediments, a thin coarse grain sand layer of about $1 \mathrm{~cm}$ thickness could be observed under the surface clay layer at this site. Therefore, in Table 3, the thickness of sand deposits at this site was estimated to be "thin" and " $0 \mathrm{~cm}$ ".

At this site, the clay surface layer was composed of sediments deposited under low energy deposition when the water stagnated at this area. As shown in Photo 20 at ARAHAMA No.9, the tortoise-shaped clay surface with thickness of $2 \mathrm{~cm}$ could be observed at the paddy field. It was difficult to determine whether it was the original ground or sediments. Thus, at this site, the clay layer was regarded as the original ground in Table $\mathbf{1}$.

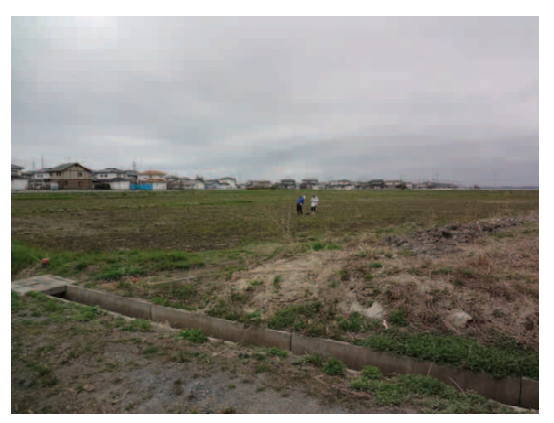

Photo 18 YOSHIDAHAMA No. 9: Facing south-east.

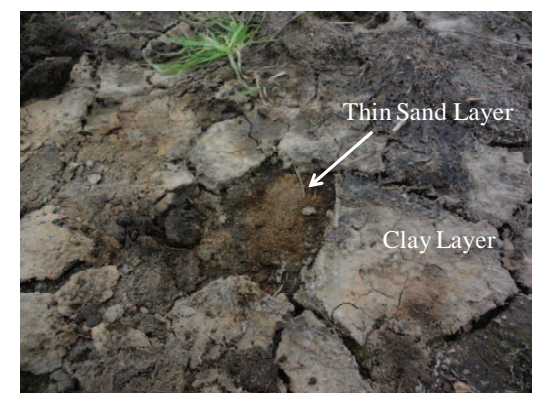

Photo 19 Thin sand layer under clay deposit.

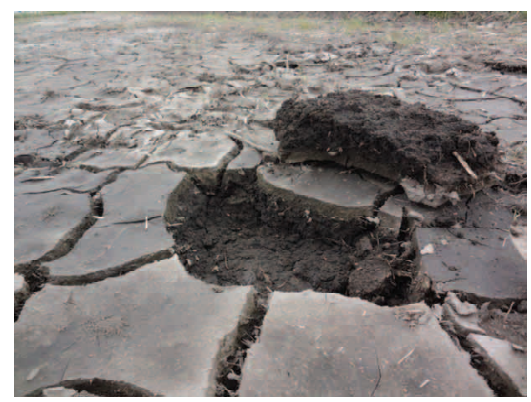

Photo 20 Clayey ground: ARAHAMA No. 9. 


\section{GRAIN SIZE OF SAND DEPOSIT}

During the field survey, except for the absence of sediments or the very thin layer which could not be sampled, the soil sampling at each site was properly applied to both sediment layers and original ground. Then, the soil types of the above samples were determined by grain-size tests such as the sieving test and sedimentation test. Moreover, by comparing the grain-size properties on the sites and layers, the characteristics of the tsunami sediments can be discussed in detail.

Sections (1) to (5) below will discuss that comparison based on grain-size distribution and/or the average particle diameter.

\section{(1) Sand characteristics at different coasts}

The sediments were carried by the tsunami from the direction of the coast. This section will verify the difference between the sands at each coast as the origin of sediments.

Fig.6 shows a comparison of the grain-size distribution between site No.1 and site No.2 at ARAHAMA, NORTH AIRPORT and YOSHIDAHAMA. Site No.1 is located close to the coastline, while site No.2 is located in front of the sea wall at the beach.

Although the sampling was conducted about one year later after the tsunami, the coastal conditions were estimated to be the same with that before the tsunami because each coast runs regularly. All samples were classified as SP and the mean diameters of No.1/No.2 were $0.32 \mathrm{~mm} / 0.39 \mathrm{~mm}$ at ARAHAMA, $0.34 \mathrm{~mm} / 0.43 \mathrm{~mm}$ at NORTH AIRPORT and 0.26 $\mathrm{mm} / 0.28 \mathrm{~mm}$ at YOSHIDAHAMA.

Therefore, the diameters of the sands at sites No.1 and No.2 at YOSHIDAHAMA were slightly smaller than those at other coasts, and the diameter of the sands at site No.2 at all coasts was a little larger than that at site No.1 in general because the sands may have been carried away from the coast by winds and/or waves.
As a further lesson, the coastal sands at ARAHAMA and NORTH AIRPORT, located in the north side at Sendai Plane, were almost similar, while the coastal sand at YOSHIDAHAMA, located in the south side at Sendai plane, was slightly smaller than those from the other two coasts.

\section{(2) Soil characteristics of original ground}

In this field survey, both paddy field and farmland were chosen as the survey sites. Furthermore, it was also expected that the different paddy fields would have different soil characteristics from each other.

Fig.7 shows the grain-size distribution of the original grounds at ARAHAMA No.3-No.8. All these distributions are almost similar. The mean particle diameters are $0.24-0.30 \mathrm{~mm}$, and the amount of fine particles are in the range of $19.9 \%-29.8 \%$. All are classified as SCs except for No. 5, which is classified as SCs-G.

Fig.8 shows the grain-size distribution of the original ground at NORTH AIRPORT No.4-No.13 (there is no sample taken at No.9). Except for No.12 and No.13, which are located far away from the coast, seven other sites are similar to the original ground at ARAHAMA. The mean particle diameter is $0.30-0.36 \mathrm{~mm}$ and the amounts of the fine particle are in the range of $3.9 \%-16.9 \%$. No.4, No.6 and No.8 are classified as SP. No.5, No.7 and No. 11 are classified as S-Cs. No.10 is classified as Cs. Unlike those at ARAHAMA and YOSHIDAHAMA, which are classified as SCs, there are many variations in composition at NORTH AIRPORT.

At NORTH AIRPORT No.12 and No.13, the amounts of fine particles are $54.8 \%$. The mean particle diameters are 0.028 (No.12) and 0.034 (No.13), and both are classified as CsS.

In short, there are two groups of the original grounds at NORTH AIRPORT that are due to the difference in the sediment environments or farmland construction works.

Fig.9 shows the grain-size distribution of the original ground at YOSHIDAHAMA No.3-No.6 (two

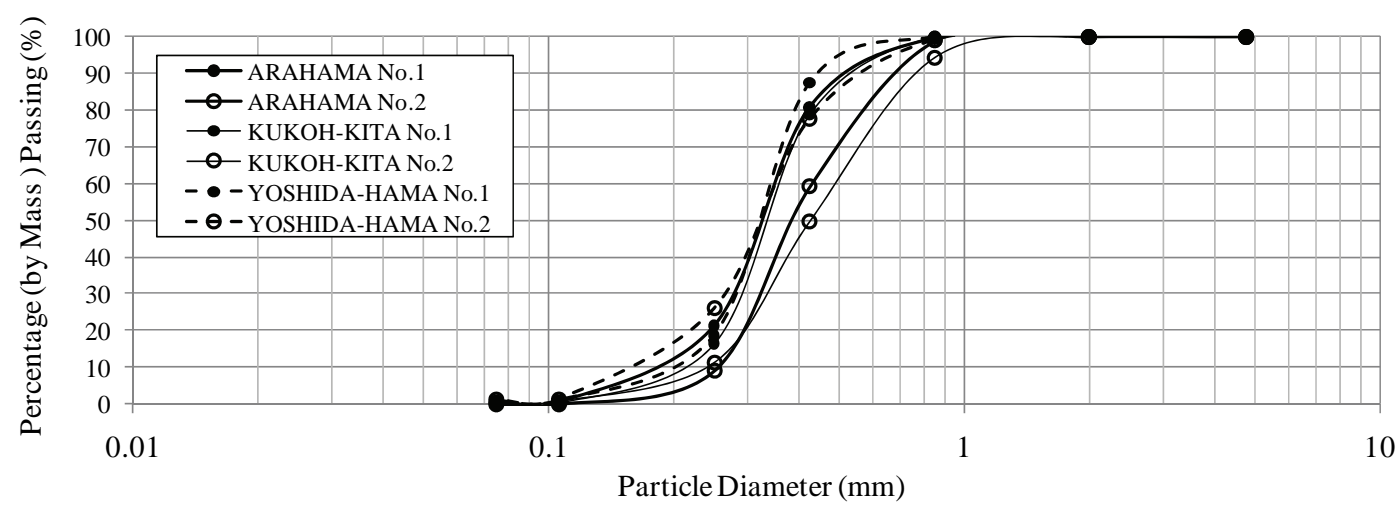

Fig.6 Grain-size distribution at three seaside areas. 


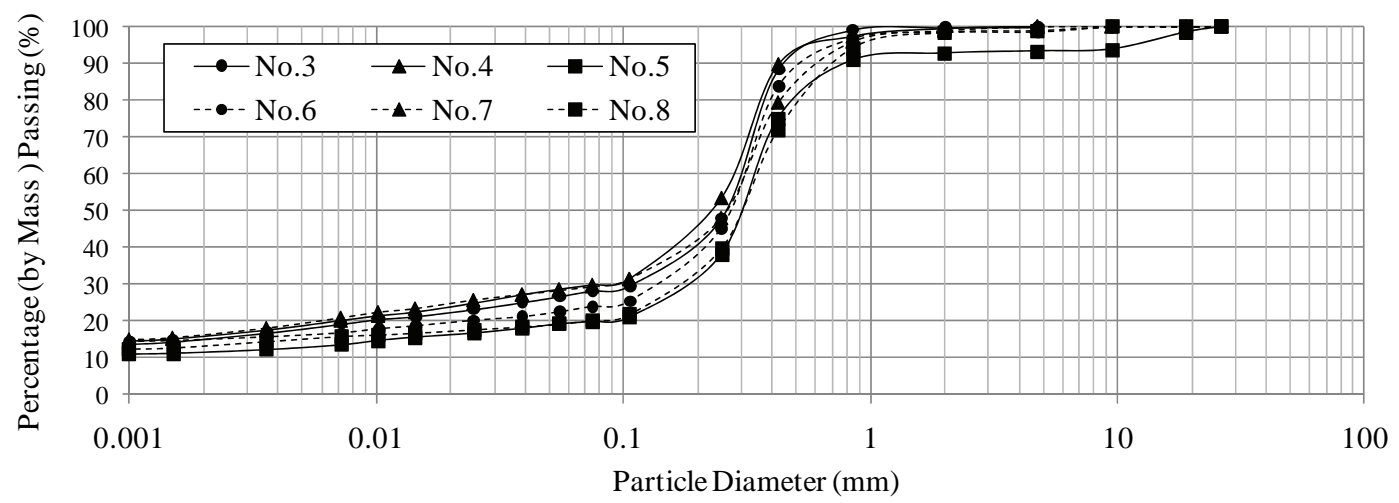

Fig.7 Grain-size distribution of original ground: ARAHAMA.

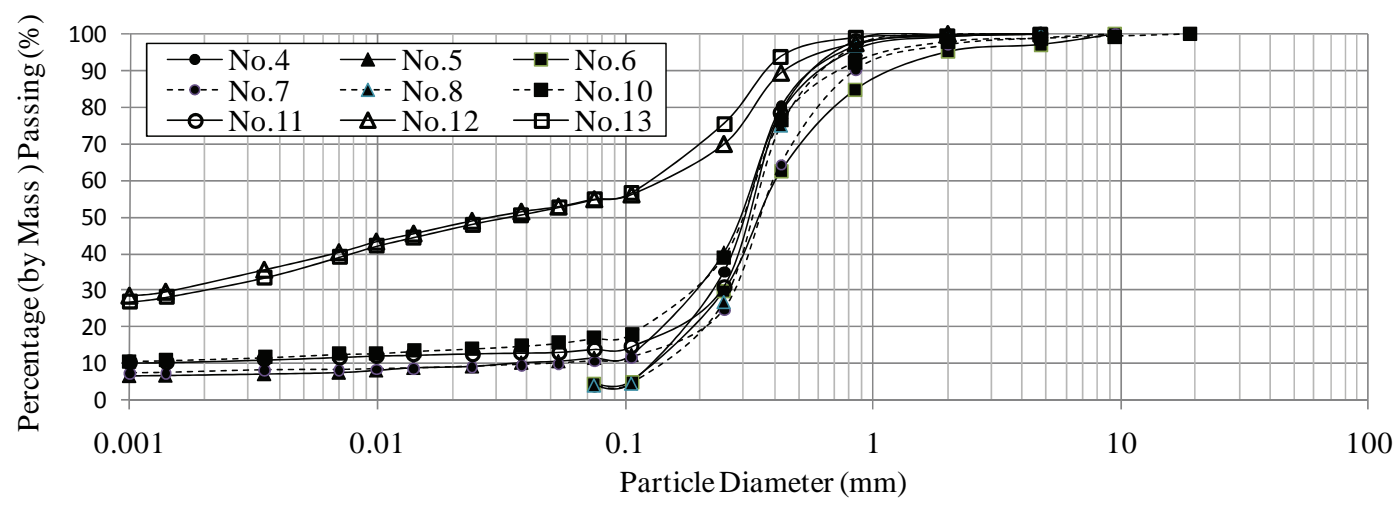

Fig.8 Grain-size distribution of original ground: NORTH AIRPORT.



Fig.9 Grain-size distribution of original ground: YOSHIDAHAMA.

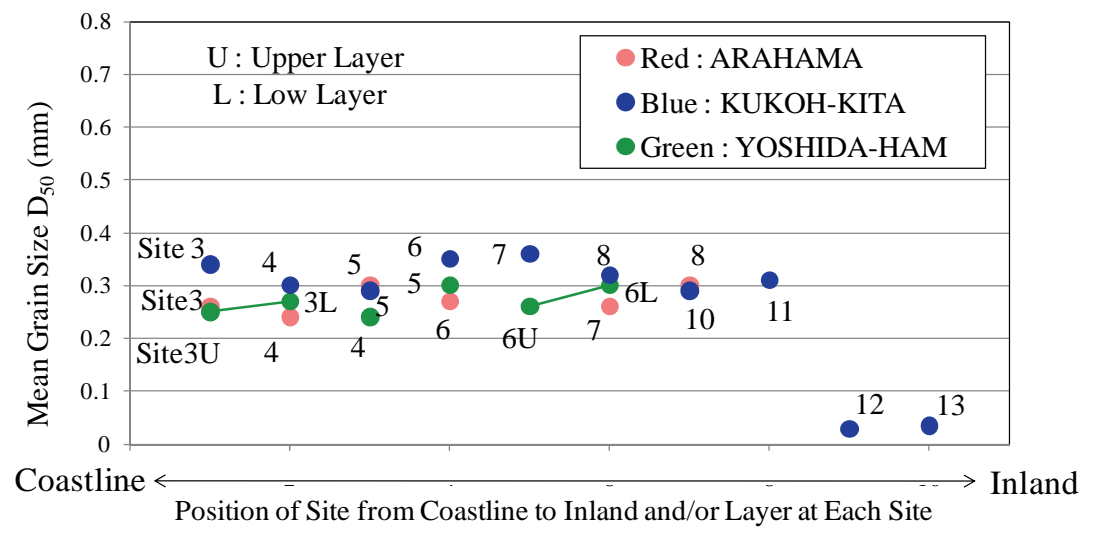

Fig.10 Average particle diameter of original grounds in three areas: The numbers represent the number of sites. 
layers at No.6), which are similar to that at ARAHAMA. The mean particle diameter is $22.5 \%$ $27.1 \%$ and all are classified as SCs, except for the lower layer at No. 6, which is classified as S-Cs, and the amount of fine particles is $14.7 \%$. All of them are almost the same.

Fig.10 shows the comparison of the average particle diameter $\left(D_{50}\right)$ of all grounds at three crosssections. In this figure, the horizontal axis represents the order of each site from the coast, i.e., the relative distance from the coastline. However, it is necessary to note that the orders between each cross-section are not related. Furthermore, for the site with plural sediment layers, the order at each site is defined from the upper layer to the lower one.

This figure shows the difference in the soil characteristics at each site and the difference in those among sediment layers at the same site. As shown in the figure, the mean particles of No.12 and No.13 at NORTH AIRPORT, which are located 2.0-3.0 km from the coast line, are finer than those from other NORTH AIRPORT, which are located 2.0-3.0 km from the coast line, are finer than those from other sites where the mean particle diameters are the same and $0.2-0.4 \mathrm{~mm}$ on the average.

Based on Fig.10, it can be concluded that there is no significant change on the grain size in the original grounds from the coastline to inland.

For YOSHIDAHAMA No.3 and No.6 where the plural original ground layers were observed, the mean particle diameter of the lower layer is larger than that of the upper one. Moreover, for all the sites, the mean particle diameters at NORTH AIRPORT except for No.12 and No.13 tend to be slightly larger than those at ARAHAMA and YOSHIDAHAMA.

\section{(3) Soil characteristics of sediment}

In this field survey, the amount of fine particles varies among the sand deposit layers. In the extreme case, the sediments consisted of clay only. Therefore, as for the tsunami deposits, it is important to discuss not only the thickness of sand layer at the field but also the soil characteristics of sediments.

Fig.11 shows the grain-size distribution of the sediment layer at ARAHAMA No.3-No.8. There are two layers at No.3 and No.4. Except for the upper layer of No.4 and the two layers at No.7, all areas have almost similar characteristics. The mean particle diameters are $0.28-0.41 \mathrm{~mm}$, and the amounts of fine particles are $2 \%-13.2 \%$. The lower layer at No.3 and layer No.8 are classified as SP, while the upper layer at No.3, the lower layer at No.4, the layer at No.5 and the layer No.6 are classified as S-Cs.

Photo 21 shows the condition of a dug pool made by the tsunami flood 20 meters away in the east side of ARAHAMA No.5, and indicates that the original ground at the dug pool was mixed with the tsunami flood and carried to the direction of No.5. This explains why the grain size at No.5 is a little coarse compared with those from other sites.

On the other hand, the sediment at No.7 is classified as CsS and the mean particle diameter is 0.016 $\mathrm{mm}$, where no sands were deposited. This indicates that far away from the coastline, even if there were no sand sediments, the fine particles were possibly deposited under the low energy deposition when the water stagnates around the site.

Fig.12 shows the distribution of sediments at NORTH AIRPORT No.4-No.13 except for No.9 without sampling. Similar to Fig.7 in the case of the original ground, except for No.12 and No.13, other seven sites are almost similar. The mean diameter is

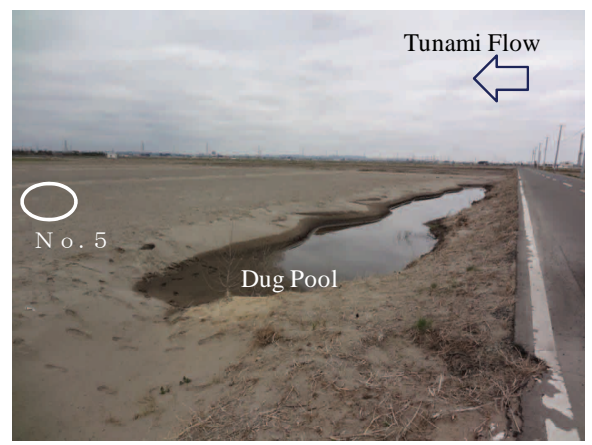

Photo 21 Dug pool behind the farm road.

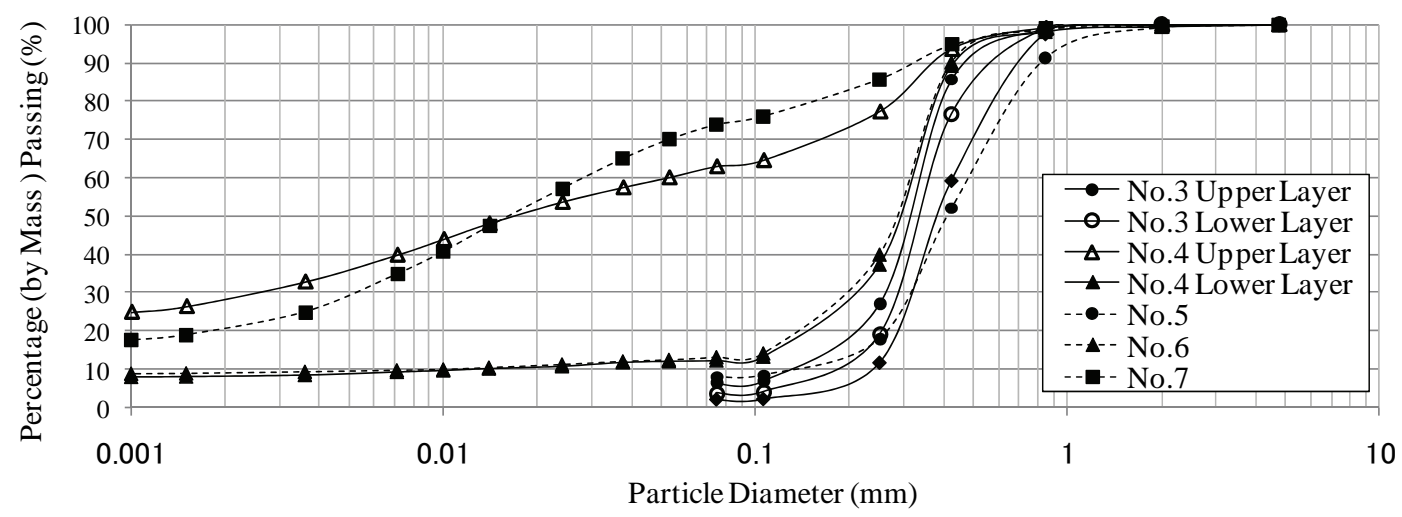

Fig.11 Grain-size distribution of sediments: ARAHAMA. 


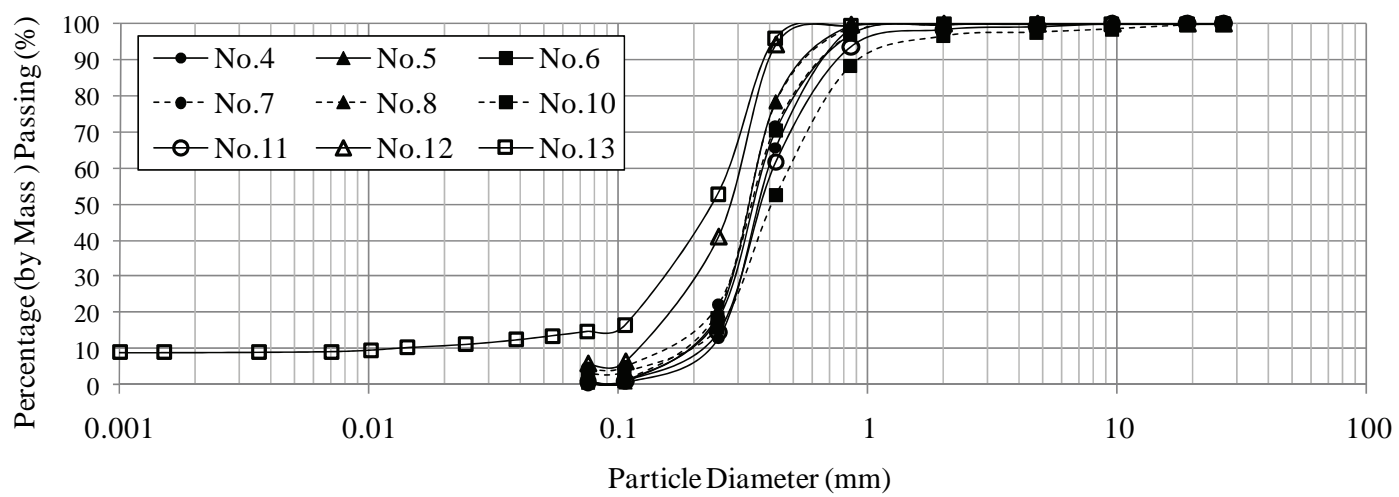

Fig.12 Grain-size distribution of sediments: NORTH AIRPORT.

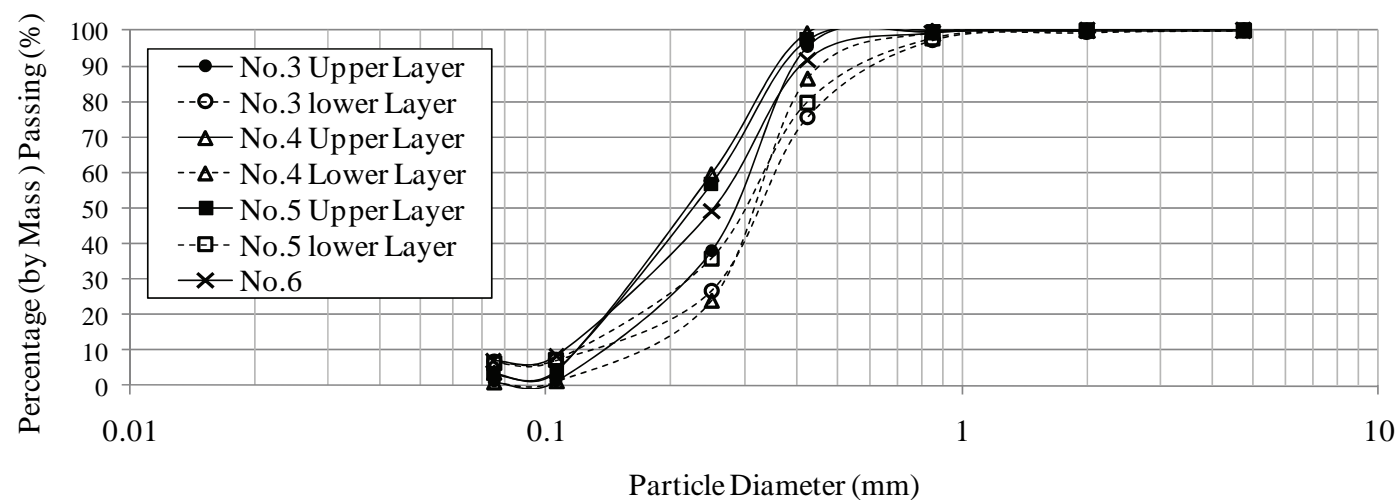

Fig.13 Grain-size distribution of sediments: YOSHIDAHAMA.

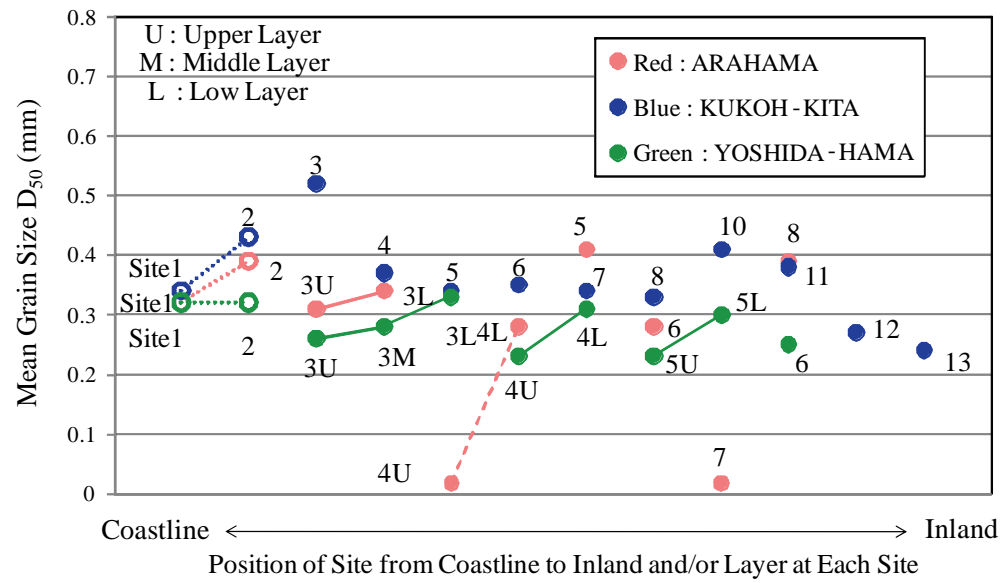

Fig.14 Average particle diameter of sediments at three cross-sections.

$0.33-0.41 \mathrm{~mm}$, and the amount of fine particles is $0.4-4.6 \%$. And all of them are classified as SP.

On the other hand, the amounts of fine particles at No.12 and No.13 are 5.7\% and $14.8 \%$, respectively. The grain size is slightly finer than those of other seven sites, and the mean particle diameters are 0.27 $\mathrm{mm}$ and $0.24 \mathrm{~mm}$, respectively. Both are classified as S-Cs.

The reason there are more fine particles at No.12 and No.13 may be due to both sites being far away from the coast. Thus, the fine particles were deposit- ed under the stagnated water.

Fig.13 shows the grain-size distribution of sediments at YOSHIDAHAMA No.3-No.6. Except for No.6 with one sediment layer, there were two sand layers at every site. The results are the same with ARAHAMA and NORTH AIRPORT. The mean particle diameters are $0.23-0.33 \mathrm{~mm}$ and the amounts of fine particle are $0.8-7.1 \%$.

The upper layer at No.3, the upper and lower layers at No.4 and the upper layer No.5 are classified as SP, while the lower layer at No.3, the lower layer at 
No.5 and the layer No.6 are classified as S-Cs. The upper and lower layers at those three sites show no clear difference.

The mean particle diameters of the upper layer/lower layer are $0.28 \mathrm{~mm} / 0.33 \mathrm{~mm}$ at No.3, 0.23 $\mathrm{mm} / 0.31 \mathrm{~mm}$ at No.4 and $0.23 \mathrm{~mm} / 0.30 \mathrm{~mm}$ at No.5. These results show that the grain size is smaller in the upper layer than that in the lower layer because of the low energy to be deposited.

Moreover, the mean particle diameter at No.6 is $0.25 \mathrm{~mm}$, which is similar to the upper layers of No.3, No.4 and No.5. However, it is smaller than those in the lower layers because No.6 is far away from the coastline.

Fig.14 shows the comparison between the mean particle diameter $\left(D_{50}\right)$ of all sediments mentioned above. Similar to Fig.9, the horizontal axis shows the order and does not reflect the exact distance from the coastline.

According to this figure, the farther the distance from the coastline is, the smaller the particle diameters tend to be. Moreover, at the sites with multiple sand sediment layers, the mean particle diameters in the upper layer are smaller than that in the lower layer. The former feature can be called "landward fining." The latter feature is generally called "fining upward." At the sites except for NORTH AIRPORT No.12 and No.13, the average particle diameters are slightly larger than those at ARAHAMA and YOSHIDAHAMA.

\section{(4) Soil characteristics at forest reserve}

The ground in the forest reserve is sand dune in general. Therefore, it is difficult to distinguish the sediments and the original ground at the field. At NORTH AIRPORT, the soil sampling was done at site No.3 in the forest reserve and the difference between the sediments and the original ground is discussed.

Fig.15 shows the grain-size distributions of No.1, No.2 and No.3 at NORTH AIRPORT. There are the upper and lower layers at No.3. Site No.1 is located at the shoreline and site No.2 is located in front of the sea wall at the beach, and both grain-size distributions are shown in the figure and compared with No.3. From this figure, the grain-size distribution of the lower layer at No.3 is similar to that at No.1 and No.2, and the lower layer can be estimated to be the original ground.

Furthermore, the mean particle diameter of upper layer of $0.52 \mathrm{~mm}$ is larger than that of the lower layer of $0.34 \mathrm{~mm}$. It can be deduced that the coarser grain was deposited earlier because the site was close to the coast

\section{(5) Boiled sand by liquefaction and tsunami sed- iments}

As shown in Photo 13, at YOSHIDAHAMA No.3, there were crater-shaped sand forms on the ground surface. Therefore, in this section, the surface sand, which was boiled sand or not by soil liquefaction, sediment sand by the tsunami and the original ground will be discussed.

Usually, the surface sand can be found on the ground surface after the earthquake. However, at this site, there was also tsunami sediment sand found under the surface sand. If the surface sand was considered to be the boiled sand layer, it will lead to the conclusion that the liquefaction occurred after the first tsunami surge. Thus, the liquefaction must have occurred during the aftershock instead of during the main shock at 14:46 on March 11.

On March 11, the maximum aftershock of M 7.7 occurred at $15: 15^{4)}$. On the other hand, the first wave of the tsunami related to the main shock came to the coastline along Sendai Plain at about 15:50. Thus, it can be concluded that the surface sand shown in Photo 14 is not the boiled sand by soil liquefaction caused by the main shock at 14:46 or aftershock at 15:15.

Fig.16 shows the comparison of the grain-size distribution between the surface sand, which was estimated to be the boiled sand layer at the field, upper and lower sediment layers of the sand deposits

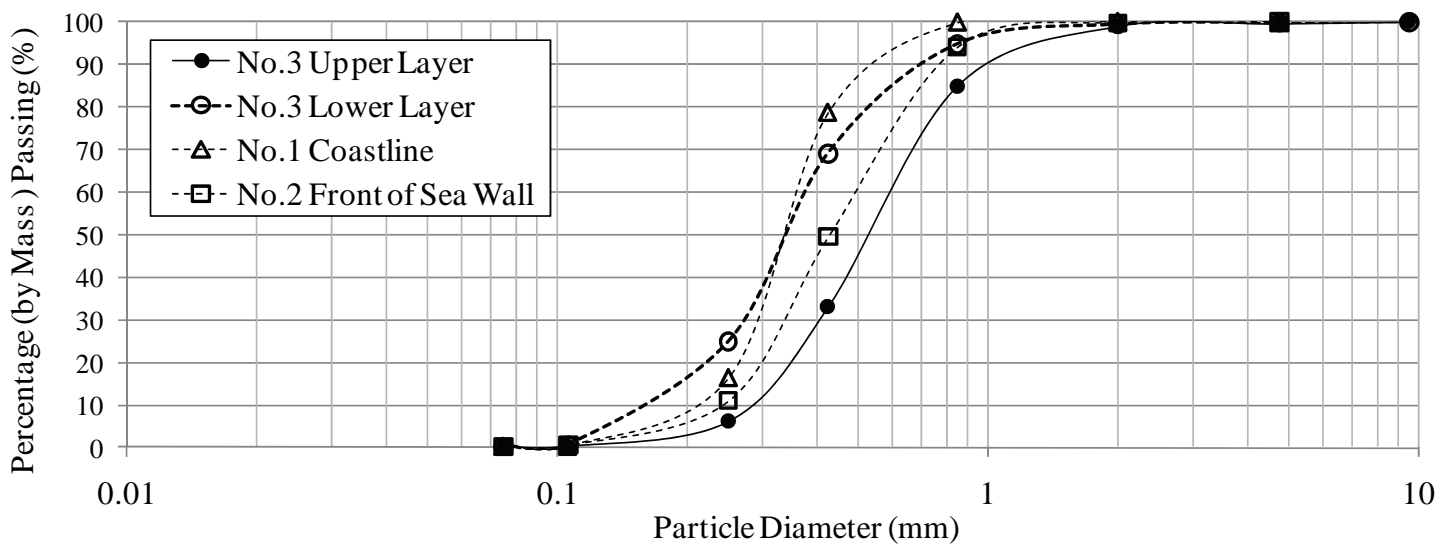

Fig.15 Grain-size distribution of sediments at forest reserve and seaside: NORTH AIRPORT. 
and the lower sand layer found under the original ground shown in Photo 14.

The estimated boiled sand on the ground surface is classified as SP, which consists of $97.5 \%$ sand and $2.5 \%$ fine particles, and $0.26 \mathrm{~mm}$ of mean particle diameter. The upper sediment sand is classified as SP, which consists of $98.9 \%$ sand and $1.1 \%$ fine particle, and $0.28 \mathrm{~mm}$ of mean particle diameter.

As shown above, the grain-size characteristic of the estimated boiled sand seems to be very similar to that of the upper sediment sand. Therefore, it can be concluded that both sands are the same.

In addition, there are finer particles in the estimated boiled sand than in the upper sediment sand. The reason can be traced to the "fining upward" feature as shown at ARAHAMA No.3. Moreover, the estimated boiled sand and the upper sediment sand are slightly different from the lower sediment sand classified as S-Cs, which consists of $92.8 \%$ sand and

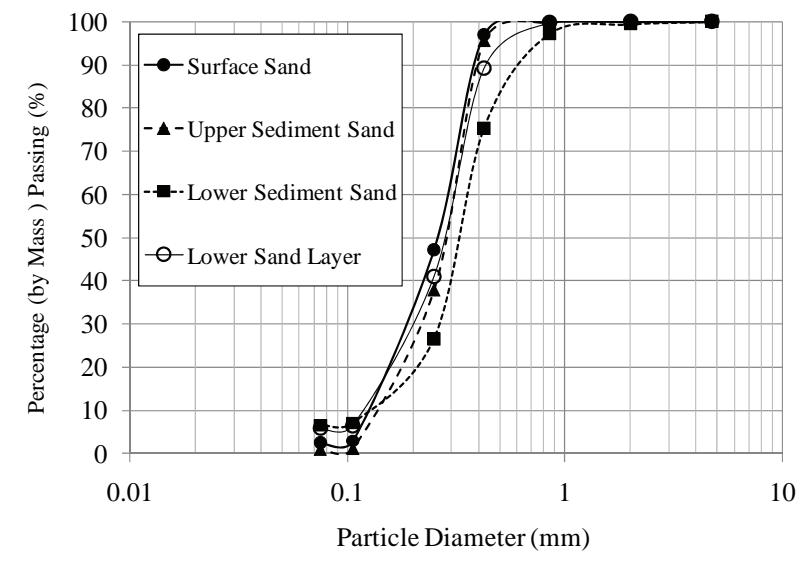

Fig.16 Relationship between surface sand, sediment sand layers and sandy ground layer.
$6.6 \%$ fine particles, and $0.33 \mathrm{~mm}$ of mean particle diameter.

Furthermore, the lower sand layer under the original ground layer is classified as S-Cs, which consists of $94.2 \%$ sand and 5.8\% fine particles, and 0.29 $\mathrm{mm}$ in mean particle diameter. Thus, the grain-size characteristics of the lower sand layer can be considered similar to that of the lower sediment sand.

Thus, it can be estimated that the surface and the upper sediment sand had been carried by the tsuna$\mathrm{mi}$, while the lower sediment sand can be considered as boiled sands by the soil liquefaction related to the main shock at 14:46 or the maximum aftershock at 15:15 as shown in Fig.5.

In addition, the lower sediment sand is a little coarser than that of the lower sand layer as shown in Fig.16 probably because the fine particles are easily washed away underneath an upward movement.

\section{DISCUSSION ON CHARACTERISTICS OF SEDIMENTS}

\section{(1) Sediment thickness and distance from coast}

In investigating the characteristics of the sediments, not only the individual characteristics at each site but also the distribution are necessary and important from a wider perspective. In this chapter, 25 sites: 7 sites at ARAHAMA, 10 sites at NORTH AIRPORT, 8 sites at YOSHIDA-HAMA out of 33 sites in this field survey were selected excluding the sites at the coast and in the forest reserve and Idoura No.1.

Fig.17 summarizes the relationship between thickness of sandy sediments and the distance from

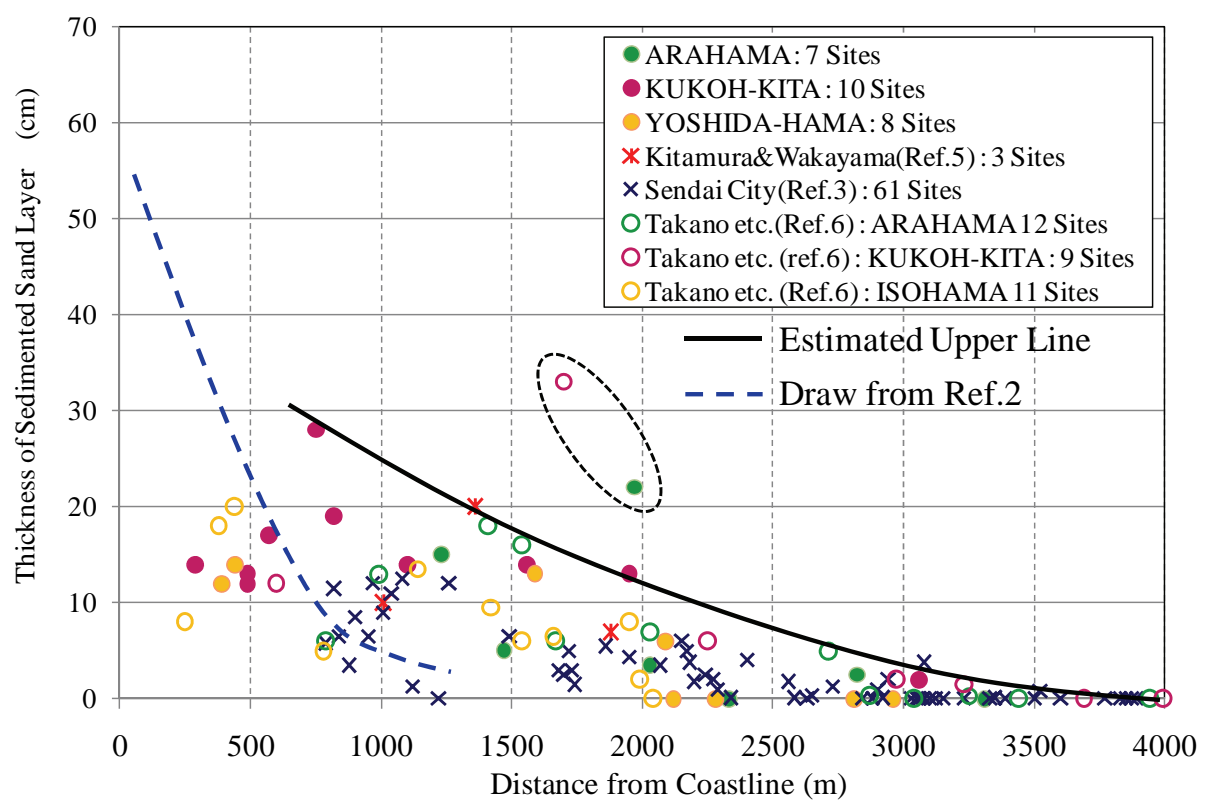

Fig.17 Relationship between thickness of sediment sand layer and distance from coastline. 
the coastline estimated from Fig.2-4 photographed on April 11 in 2012. This figure also refers to the related data reported by other investigators: 3 sites at ARAHAMA by Kitamura \&Wakayama ${ }^{5)}$, 81 sites by Sendai City $^{3)}$ and 32 sites at ARAHAMA (12 sites), KUKOH-KITA (9 sites) and ISOHAMA (11 sites) by Takano et al. ${ }^{6}$. The distance from the coastline on the sites investigated by Sendai City is calculated based on the site location map by the authors. It should be noted that the distance from the coastline shown in each result is not exactly related to each other. However, because the above data were investigated within a year after the earthquake and the coastline did not change much, comparing the data in this survey with other data was considered possible.

As seen in Fig.17, the sediment thickness tends to decrease with the increase of the distance from the coastline. It can be noted that the limitation of the distance more than $10 \mathrm{~cm}$ of the thickness is about 2 $\mathrm{km}$, while the limitation for more than $5 \mathrm{~cm}$ is about $2.5 \mathrm{~km}$.

Fig.18 shows the survey result of sediments by Sczuzinski ${ }^{2)}$ along the Andaman Sea Coast in Thailand after the Indian Ocean tsunami induced by the great earthquake that occurred off the west coast of northern Sumatra with a surface wave magnitude (Ms) of 9.0 on December 26 in 2004. In this survey, the soil type of sediments was not mentioned. But as the figure shows, the thickness of sediments on the run-up height may be known to decrease with the distance from the coastline. Moreover, in the shaded area in Fig.18, the retention limits of the sediments, which refer to the minimum condition for the remaining sediment show the thickness of more than $10 \mathrm{~cm}$ and the run-up height of more than $3 \mathrm{~m}$.

Furthermore, as shown in the figure, the maximum distance of the sediment deposition is about $1,200 \mathrm{~m}$ from the coastline. On the other hand, because the maximum distance in Fig.17 is about 3.5 $\mathrm{km}$ at Sendai Plain, the influenced area scale in the 2004 Indian Ocean tsunami in Thailand can be considered to be $1 / 2.5-1 / 3$ of that by the tsunami in the 3.11 Earthquake.

The two upper lines (black solid line and blue broken line) are drawn in Fig.17 to indicate the maxi-mum value of the sediment thickness by the tsunami relating to the distance from the coastline for the future tsunami. Although the authors estimated the broken line in Fig.18, it should be noted that the soil type of the sediments, i.e., sand or clay, is unknown as mentioned above.

Here, the two sites encircled by a dotted line on top of the solid line shown in Fig.17 are the sites reported by Takano et al. ${ }^{6}$ located at the distance of $1,700 \mathrm{~m}$ from the coastline with the sediment thick- ness of $33 \mathrm{~cm}$, and the other site at ARAHAMA No.5 surveyed by the authors located at the distance of $1,970 \mathrm{~m}$ with the thickness of $22 \mathrm{~cm}$. The former was said to be located in the lowland and the latter was said to be located along the pass and was affected by the sediments coming from the dug pool shown in Photo 21.

\section{(2) Deposition of coarse and fine particles}

Sendai City surveyed the sediments at 61 farmland sites at Sendai Plain ${ }^{3}$. The farmlands are located within about $4 \mathrm{~km}$ from the coastline in the eastwest direction and about $10 \mathrm{~km}$ from Nanakita River to Natori River in the north-south direction. The purpose of this survey was to investigate the pollution in the farmlands. Therefore, the sediment thickness was not emphasized. However, the thickness of the mud and/or sand layers on the ground surface at 61 sites were reported as shown in Table 4, where the mud was regarded as clay in this paper.

The above data indicate that the mud layer is generally deposited above the sand layer. As shown in Table 4, the thickness of sediments at 9 sites out of 61 ones is $0 \mathrm{~cm}$. Thus, the sediments were observed at 52 sites.

Furthermore, the sediment layer compositions were classified into three types: sand layer at 5 sites, mud layer at 10 sites and sand and mud layer at 37 sites. Unlike previous surveys, in this survey, there were many sites where the mud layer was above the

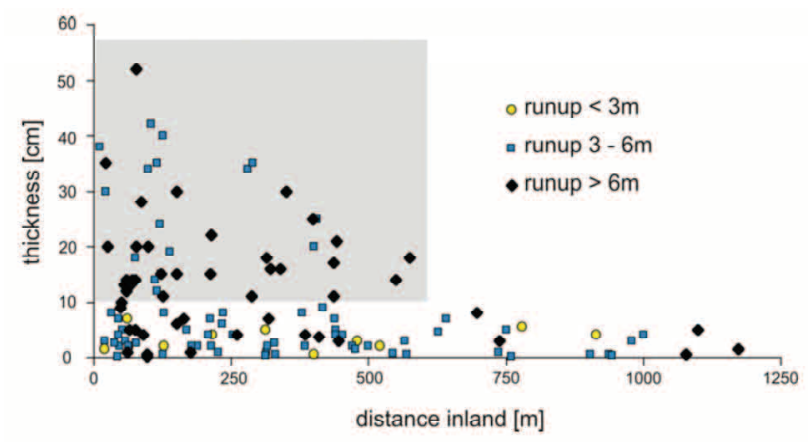

Fig.18 Thickness of Indian Ocean tsunami deposit at Andaman Sea Coast, Thailand, 2004²).

Table 4 Sediment condition ${ }^{3)}$.

\begin{tabular}{|c|c|c|c|c|c|c|}
\hline \multirow{2}{*}{$\begin{array}{c}\text { Thickness of Sediment } \\
\text { Layer H }\end{array}$} & \multicolumn{3}{|c|}{ Number of Sites on Soil } & \multicolumn{3}{|c|}{ Number of Sites on Layer } \\
\hline & Total & $\begin{array}{l}\text { Sand } \\
\text { Layer }\end{array}$ & $\begin{array}{l}\text { Mud } \\
\text { layer }\end{array}$ & $\begin{array}{c}\text { Sand and } \\
\text { Mud }\end{array}$ & $\begin{array}{l}\text { Only } \\
\text { Sand }\end{array}$ & $\begin{array}{l}\text { Only } \\
\text { Mud }\end{array}$ \\
\hline $0 \mathrm{~cm}$ & 9 & 21 & 14 & - & - & - \\
\hline $0 \mathrm{~cm} \leq \mathrm{H}<5 \mathrm{~cm}$ & 29 & 25 & 44 & 15 & 4 & 10 \\
\hline $5 \mathrm{~cm} \leq \mathrm{H}<10 \mathrm{~cm}$ & 16 & 10 & 3 & 16 & 0 & 0 \\
\hline $10 \mathrm{~cm} \leq \mathrm{H}$ & 7 & 5 & 0 & 6 & 1 & 0 \\
\hline \multirow{2}{*}{ Total } & \multirow{2}{*}{\multicolumn{3}{|c|}{61 Sites }} & 37 Sites & 5 Sites & 10 Sites \\
\hline & & & & \multicolumn{3}{|c|}{52 Sites } \\
\hline Max. Thickness (cm) & 14.0 & 12.5 & 9.5 & 14.0 & 12.5 & 4.3 \\
\hline Min. Thickness (cm) & 0.3 & 0.1 & 0.1 & 1.5 & 0.8 & 0.3 \\
\hline Ave. Thickness (cm) & 5.1 & 4.2 & 2.0 & 6.1 & 4.8 & 1.6 \\
\hline
\end{tabular}




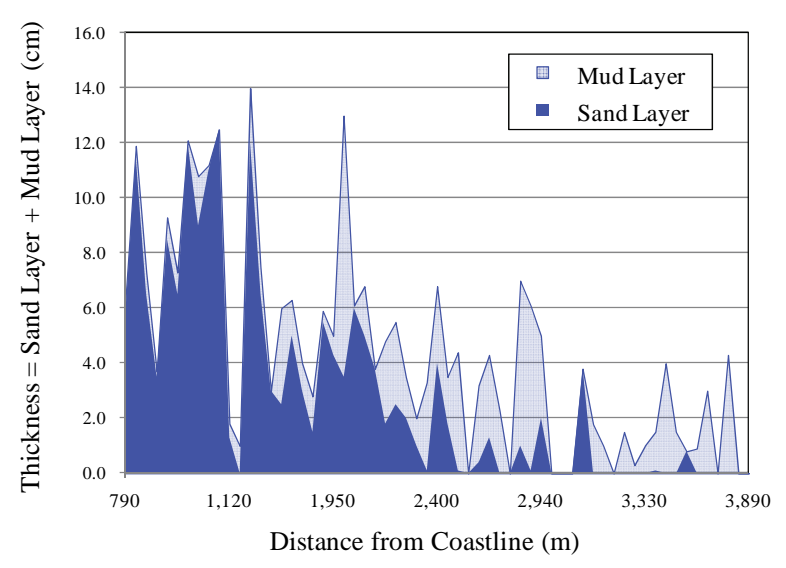

Fig.19 Thickness of mud and/or sand sediment and distance from coastline drawn from Ref.3).

sand layer, i.e., three-layer structure. The maximum thickness of the sand layer, mud layer and sand and mud layer were $14 \mathrm{~cm}, 12.5 \mathrm{~cm}$ and $9.5 \mathrm{~cm}$, respectively, while the average thicknesses were $5.1 \mathrm{~cm}$, $4.2 \mathrm{~cm}$ and $12.0 \mathrm{~cm}$, respectively.

Referring to 61 sites in Table 4, Fig.19 shows the relationship between the thickness of mud and/or sand layers and the distance from the coastline. The distance was measured by the authors from a Google map picture photographed on April 6 in 2011. The measurement error is about $\pm 20 \mathrm{~m}$ and 61 sites located in the range of 700-3,900 $\mathrm{m}$ from the coastline.

From Fig.19, it can be noted in general that the closer to the coastline the site is, the thicker the sediment is; and the farther from the coastline the site is, the muddier the sediment is. These trends mean that the fine and light particles are carried far and deposited slowly. As shown previously, the above deposition characteristic can be called "landward fining" and "fining upward."

\section{(3) Sand deposit by the Jogan tsunami}

Sawai et al. ${ }^{7)}$ surveyed the old tsunami traces at Sendai City (hereinafter S2), Natori City (ditto, N1), Watari town (ditto, W3) and Yamamoto town (ditto, Y2) at Sendai Plain before the 3.11 Earthquake.

From their survey results, the data on the thickness of the sand sediments can be deduced, which they called the "event" sand layer deposited by the Jogan tsunami, which occurred during the 869 Jogan Earthquake in the Tohoku Region with the same severe impact as the 3.11 Earthquake.

Fig.20 independently drawn by the authors referring to the thickness of the event sand layers reported by Sawai et al. ${ }^{7)}$ summarizes the relationship between the order of each site from the coastline and the thickness of the "event" sand layer selected by the authors at 77 sites in 6 zones: 24 sites at Sendai A and 17 sites at Sendai B, 17 sites at Natori, 2 sites

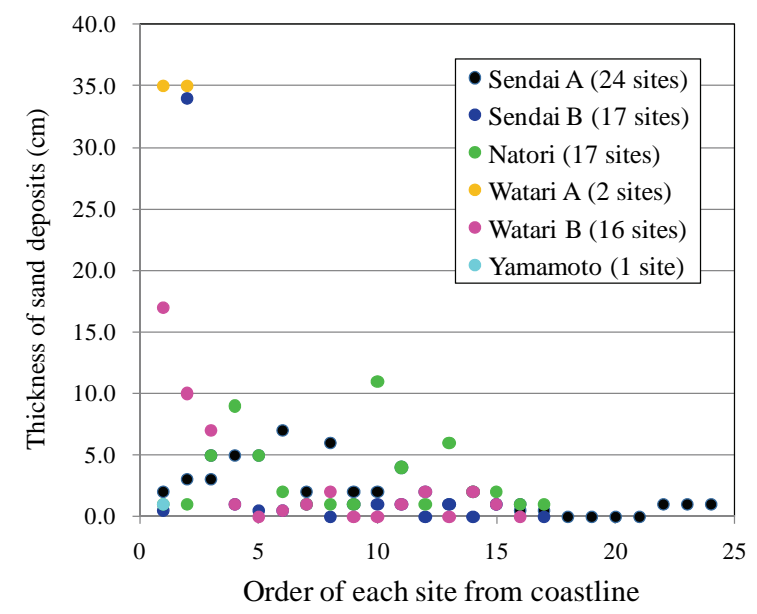

Fig.20 Thickness of "event” sand layer and order of site from coastline drawn from Ref.7).

at Watari A and 16 sites at Watari B and 1 site at Yamamoto whose thickness is reported numerically or estimated to be $0 \mathrm{~cm}$ by the authors independently when the thickness of the event sand layer is very thin and not reported numerically.

Sawai et al. ${ }^{7)}$ mentioned that at that time in 869, the coastline, compared with the present one, was 0.5-1.0 km landward at Sendai City and Natori City, and 1.0-1.5 km landward at Watari town and Yamamoto town. Because the coastline in 869 was not mentioned, the lateral axis in Fig.20 tries to identify the order of each site from the present coastline, which does not indicate the real distance similar to Fig.10 and Fig.14. Thus, the smaller the number of the order is, the closer to the coastline the site is.

It can be seen in Fig.20 that the thickness of the "event" sand layer tends to decrease with the increase of the order of the site. Furthermore, the maximum thickness among 77 sites is $35 \mathrm{~cm}$, and there are 6 sites with $10 \mathrm{~cm}$ or more in thickness, 10 sites with 5-10 cm and 61 sites with less than $5 \mathrm{~cm}$. There are 13 sites out of 61 sites where the numerical thickness of the "event" sand layer was not mentioned by Sawai et al. ${ }^{7)}$

Comparing the thickness of the sand sediments of this time tsunami shown in Fig.17 with that of the Jogan tsunami shown in Fig.20, it can be seen that the former seems to be a little larger than that of the latter. However, as the years went by after the 869 Jogan tsunami, the "event" sand layer has been changed, for example, because of compaction. Comparing Fig.17 with Fig.20, the sand sediment from this time tsunami can be seen to be almost the same with that from the Jogan tsunami.

Furthermore, Sawai et al. ${ }^{7)}$ reported that the runup distance of the Jogan tsunami from the coastline at that time was estimated at least $1 \mathrm{~km}$ at Sendai City, at least $4 \mathrm{~km}$ at Natori City, about $2.5 \mathrm{~km}$ at 
Watari town and about $1.5 \mathrm{~km}$ at Yamamoto town. Thus, comparing the above run-up distance with the maximum distance estimated from sediments in the 3.11 Earthquake, the run-up distance of the Jogan tsunami seems shorter than that of the time tsunami. Sawai et al. ${ }^{7)}$ explained that the flooded area identified from the "event" sand sediment tended to be smaller than that of the real area where fine particle sediments were easily carried away.

However, the "event" sand layer mentioned above consisted of coarse sand particles, and the sediments including not only sand but also clay were carried inland. Therefore, to determine the real runup distance, the clayey sediment as a trace index of the tsunami sediments should be examined. However, it was very difficult to study the soil profile of the thin clayey layer carried by the tsunami.

\section{CONCLUSION}

In this study, the field survey on the sediments by the tsunami on March 11 during the 2011 off the Pacific Coast of Tohoku Earthquake was conducted at three cross-sections in the Sendai Plain. Both soil samples and grain-size distribution tests were conducted for a detailed study of the characteristics of the sediments, not only the site condition but also the grain size.

The findings obtained in this study are very important and useful lessons that can be applied as fundamental data to estimate the sediments volume and its distribution for reconstruction works and tsunami simulation on flood depth and flow velocity inland in the future.

1) In this survey, the discussion was mainly whether sediments were present or not, without considering the difference in the surface conditions as an affecting factor. It was found that the soil deposition was not necessarily deposited uniformly and spread widely, and it changed with a slight difference in the surface shape. Therefore, even though a field survey on past sediments under the ground will be done, it should be noted that the presence or not of the sand sediment and its thickness depend on the deposition environment.

2) The sediment layer and the original ground at the field were distinguished with the use of several points such as the color of layer, vision or coarse/fine texture, vegetation and impurity. Comparing the field judgment with the grain-size test result, the above points are found to be very appropriate.

3) The soil composition of sediments was mainly classified into three types, namely the sand layer, clay layer and composed layer by sand and clay.
Due to the distance from the coastline and the stagnant water condition, the characteristics of the sediments can be described as follows:

3-1) In the case of sand deposit, there may be a difference in the grain-size distributions between the upper and lower layers, i.e., there are more fine particles in the upper layer than in the lower one. This sediment characteristic can be called "fining upward" due to the different times of deposition because the fine particles were deposited later than the coarser ones.

3-2) In the case of clay deposit, there may be differences in the grain-size distribution according to the distance from the coastline. This sediment characteristic can be called "landward fining," because the fine particles were easily carried away and deposited under the water that stagnated after the tsunami. The clay particles came not only from offshore but also from inland ground eroded by the tsunami.

3-3) In the case of sand and clay-composed deposits, there may be differences in the grain-size distribution between the sand layer and the clay one. In general, the clay layer is located in the upper sand layer, and this sediment characteristic can also be called "fining upward" due to the difference in the grain size between sand particles and clay ones. However, there were few sites where the clay layer was deposited above the sand layer in this survey, and many sites corresponding to the above conditions were reported in Sendai City.

4) To clarify the rise of sediments, especially sands, the grain-size distribution of soils at the shore were investigated. However, the inland sediments contained fine particles and were not the same with those at the shore. The reason for the interfusion of fine particles is mentioned in 3-2).

5) At the forest reserve and farmland close to the coast, the original ground often consists of sands. Thus, the examination of sand deposits on the original sandy ground at the above sites should be done carefully.

6) The sand sediments result from sands transferred from the shore and sands boiled by liquefaction and eroded by the tsunami flood on the ground surface. Therefore, it is necessary to pay attention to the rise of the sands deposited

7) The relationship between the thickness of sand sediments and the distance from the coastline including the data reported by other investigators can be summarized in Fig.17, which shows that the thickness of sand sediments tends to decrease with increase in the distance.

\section{REFERENCES}

1) Active Fault and Earthquake Research Center Geological Survey of Japan AIST Web Site: Study of past huge Tsuna- 
mi by using Tsunami sediment, Preliminary Report on the pacific coast of Tohoku earthquake, 2011.6.9 update. (in Japanese)

2) Szczucinski, W.: The post-depositional change of the onshore 2004 tsunami deposits on the Andaman Sea coast of Thailand, Nat Hazards, DOTI 10.1007/s11069-011-9956-8, open access at Springerlink.com, published online:31 August 2011.

3) Sendai City: Survey results of soils deposited on farmlands damaged by tsunami -Quick Report-, Report of $6^{\text {th }}$ Committee Meeting of Sendai Eastern District Agricultural Disaster Recovery Committee, No.10, 2011.8.9. (in Japanese)

4) Japan Meteorological Agency: Aftershocks in the 2011 Off the Pacific Coast of Tohoku Earthquake (Part 21), Press release material. 2011.3.18.17:30. (in Japanese)

5) Kitamura, A. and Wakayama, N.: Field observation of run-up tsunami deposits around Onuma at Sendai Plain, Report on Earth and Science of Shizuoka University, No.38, pp.1-2, 2011. (in Japanese)

6) Takano, K., Ouchi, M., Niiyama, M., Itoh, Y. and Nakakura, H.: Tsunami deposits in the off the Pacific Coast of Tohoku Earthquake, Technical Report of Tohoku Geotechnical Survey Association, Daichi, No.52, pp.30-39, 2012. (in Japanese)

7) Sawai, Y., Shishikura, M. and Komatsubara, J.: A study on paleotsunami using hand corer in Sendai plain (Sendai City, Natori City, Iwanuma City, Watari Town, Yamamoto Town), Research Report on Active Fault and Paleoearthquake, No.8, pp.17-70, 2008. (in Japanese)

(Received July 1, 2013) 